\title{
Climate and human impact on a meromictic lake during the last 6000 years (Montcortès Lake, Central Pyrenees, Spain)
}

\author{
Juan Pablo Corella ${ }^{1 *}$, Ana Moreno ${ }^{1}$, Mario Morellón ${ }^{1}$, Valentí Rull ${ }^{2}$, Santiago Giralt ${ }^{3}$, \\ María Teresa Rico ${ }^{1}$, Ana Pérez-Sanz ${ }^{1}$ Blas Lorenzo Valero-Garcés ${ }^{1}$ \\ ${ }^{1}$ Instituto Pirenaico de Ecología (CSIC). Departamento de Procesos Geoambientales y \\ Cambio Global. Avda. Montañana 1005, 50059 Zaragoza, Spain. \\ ${ }^{2}$ Institut de Botànic de Barcelona (CSIC), Passeig del Migdia s/n, 08038 Barcelona, \\ Spain \\ ${ }^{3}$ Instituto de Ciencias de la Tierra Jaume Almera (CSIC), C/Lluís Solé i Sabarís s/n, 08028 \\ Barcelona, Spain
}




\section{ABSTRACT}

Sedimentological, mineralogical and compositional analyses performed on short gravity and long Kullenberg cores from meromictic Montcortès Lake (Pre-Pyrenean Range, NE Spain) reveal large depositional and paleohydrological changes during the last $6000 \mathrm{cal}$. years BP. The limnological characteristics of this karstic lake, including its meromictic nature, relatively high surface/depth ratio (Surface about $0.1 \mathrm{~km}^{2} ; \mathrm{Zmax}=30 \mathrm{~m}$ ), and steep margins, have facilitated the deposition and preservation of finely laminated facies, punctuated by clastic layers corresponding to turbidite events. Relatively shallower lake conditions prevailed during the Mid Holocene (6000-3500 cal. years BP), and deeper environments with deposition of varves with calcite laminae preservation occurred afterwards. Increased carbonate productivity and lower clastic input occurred during the Iberian-Roman Humid Period, the Little Ice Age and the $20^{\text {th }}$ century. Two episodes of higher clastic input to the lake developed: i) during the period 690-1460 AD, coinciding with an increase in the farming activity in the area and the Medieval Climate Anomaly; and ii) between 1770 and 1950 AD, coinciding with the last phases of the Little Ice Age and the maximum human occupation of the mountain areas in the Pyrenees. Slope instability has caused large gravitational deposits during the Mid Holocene (prior to $6 \mathrm{ka}$ ) and Late Holocene (prior to 1600 and $1010 \mathrm{cal}$. yr BP).

Keywords: Lake Montcortès, Western Mediterranean, Pyrenees, Holocene, varves, Human impact, Little Ice Age 


\section{INTRODUCTION}

Recent studies have shown a large hydrological variability in the Mediterranean Basin during the Holocene, with a complex fluctuation of arid and humid periods in response to changes in orbital configuration and insolation (Liu et al. 2006) and Atlantic Ocean dynamics, i.e., North Atlantic Bond Cycles (Bond et al. 1997; 2001). The last millennia are of particular interest because the main boundary conditions have been similar to present-day climate configurations and detailed regional palaeoclimatic reconstructions can be compared to current climate change processes (Wanner et al. 2008).

In the Iberian Peninsula, the number of available Holocene lacustrine records has greatly increased during the last decades (e.g., Davis 1994; Pérez-Obiol and Julià 1994; Allen et al. 1996; Giralt et al. 1999; Valero-Garcés et al. 2000a,b; Luque and Julià 2002; González-Sampériz et al. 2005, 2008; Moreno et al. 2008; Morellón et al. 2008; Moreno et al. 2009; Morellón et al. 2009, in press-a, in press-b). However, most of them lack the chronological resolution to resolve the sub-millennial variability during the Holocene. Several paleohydrological fluctuations have been described in a number of Spanish lacustrine records during the Late Holocene, e.g., Zoñar Lake (Martín-Puertas et al. 2008), Taravilla Lake (Moreno et al. 2008), Estanya Lake (Morellón et al. 2008, in press-a), Lake Redó (Pla and Catalan, 2005), and they seem to have a regional impact, particularly the 4 ka aridity crisis, the Iberian-Roman Humid Period, the dry and warm Medieval Climate Anomaly and the cold, with some humid phases, Little Ice Age. On the other hand, the human impact in the lake watersheds in the Mediterranean region is noticeable since Neolithic times and especially higher during the last two millennia.

However, the precise dating of these climatic fluctuations, their regional variability and their interplay with the intense human impact in the lake watersheds since Neolithic times and, in particular during the last two millennia is still unknown in the Iberian Peninsula. Thus, in order to understand the internal Holocene hydrological variability in the western Mediterranean area, more reconstructions with adequate dating and resolution are required. In the Iberian Peninsula, karstic lakes may provide such records. The relatively small size of perennial, freshwater, karstic lake systems, their hydrologically and topographically closed basins and the connection to aquifers make these lacustrine systems very sensitive to regional hydrological balances, 
experiencing considerable lake level, water chemistry and biological fluctuations in response to changes in effective moisture (Cohen 2003; Morellón et al. 2009). Sedimentary sequences of karstic lakes in Spain also record the impact of human activities during the last centuries, such as Lake Chiprana (Valero-Garcés et al. 2000b) and Lake Zoñar (Valero-Garcés et al. 2006), and millennia, like Estanya Lake (Morellón et al. 2008, 2009), Lake Zoñar (Martín-Puertas et al. 2008, 2009), Lake Banyoles (Pérez-Obiol and Julià 1994), and La Cruz Lake (Romero-Viana et al. 2008), among others. Most karstic lakes in Spain have a morphometry characterized by circular basins with step margins and a relatively high depth/area relationship favouring water stratification (Miracle et al. 1992). Permanent meromixis, however, is a peculiar condition found only in a few lakes in the Iberian Peninsula (Miracle et al. 1992). The meromictic nature of these lakes and the strong seasonality of the Mediterranean climate, together with the occurrence of algal blooms in spring, are conducive to the genesis and preservation of varved records, as in Lake La Cruz (Julià et al. 1998; Romero-Viana et al. 2008) or Lake Zoñar (Martín-Puertas et al. 2009).

In this paper, we investigate the finely-laminated sedimentary sequence with a decadal to centennial resolution spanning the last 6000 years of Lake Montcortès, a karstic, deep (up to $30 \mathrm{~m}$ of water depth) and meromictic lake in the Pre-Pyrenean Mountains. This paleoenvironmental reconstruction is based on sedimentological, mineralogical and compositional analyses of four sediment cores retrieved from the deepest area of the lake and an age model constrained by $17 \mathrm{AMS}{ }^{14} \mathrm{C}$ dates. Finely laminated facies and annual varves dominate the record and have allowed the identification of periods of increased clastic input, and changes in limnological and hydrological conditions related to climate variability and the human impact in the watershed during the studied period.

\section{STUDY SITE}

\section{Geographical and geological setting}

Lake Montcortès (42 $19^{\prime} \mathrm{N}, 0^{\circ} 59^{\prime} \mathrm{E}, 1027 \mathrm{~m}$ a.s.l.) is a karstic lake located in the PrePyrenean Range (NE Spain) (Fig. 1a). The lake sits on the northern boundary of the 
tectonic South Pyrenean Central Unit, characterized by the dominance of Mesozoic and Tertiary carbonate rocks and the occurrence of a number of thrust sheets affecting Paleozoic formations (Rosell 1994). The detachment level for the thrusts is the Upper Triassic evaporites and shales (Keuper facies). The small Lake Montcortès catchment's bedrock is composed of Triassic materials as carbonates (Muschelkalk facies), claystones and evaporites (Keuper facies) with some intrusions of hypovolcanic ophite bodies (Rosell 1994) (Fig. 1b). The presence of Muschelkalk limestones and dolostones, Oligocene carbonatic conglomerates and gypsum-rich materials (Keuper facies) have favoured karstic activity, leading to the generation of depressions by dissolution and collapse in the area (Gutiérrez et al. 2008), similarly to lakes found in other PrePyrenean zones as Estanya Lake (Morellón et al. 2008), Arreo Lake (Rico et al. 1995) or Lake Banyoles (Canals et al. 1990).

The regional climate is of Continental Mediterranean Alpine type. Mean annual precipitation and temperature are $860 \mathrm{~mm} /$ year and $10.6^{\circ} \mathrm{C}$, respectively. Monthly mean temperatures range from $1.9^{\circ} \mathrm{C}$ in January to $20.3{ }^{\circ} \mathrm{C}$ in July. March is the driest month and May is the most humid one, with mean rainfalls of $46.6 \mathrm{~mm}$ and $99.2 \mathrm{~mm}$ respectively (data from Senterada Meteorological Station, $5 \mathrm{~km}$ west of the lake).

The regional vegetation is Submediterranean and it is dominated by the BuxoQuercetum pubescentis communities. The forest formations reflect a transition between the Mid-European and Mediterranean ecosystems with trees dominated by Quercus and Pinus and shrubs dominated by Buxus sempervirens. Farm land with cereal crops and meadows cover flat areas (Blanco et al. 1997). Currently, the lake shorelines are colonized by hygrophyte communities of Juncus sp., Scirpus sp., Phragmites communis, Thypa latipholia and Sparganium (Camps et al. 1976).

\section{Hydrology and limnology}

Lake Montcortès catchment belongs to the Flamisell River watershed. Lake morphology is almost circular (maximum length is $525 \mathrm{~m}$ and maximum width is about $450 \mathrm{~m}$ ). Total shoreline length is $1320 \mathrm{~m}$ and maximum water depth is up to $30 \mathrm{~m}$ (Camps et al. 1976; Miracle and Gonzalvo 1979; Modamio et al. 1988; Cristina et al. 2000) (Fig. 1c). 
There is not permanent inlet, but ephemeral creeks drain the southern area of the catchment, providing water and clastic sediments to the lake. An outlet stream, located at the north shore is currently inactive (Camps et al. 1976), although is functional during humid periods, controlling effectively the lake level. Lake hydrology is mostly governed by groundwater input, with several springs and seepage from the main Triassic Muschelkalk aquifer (Bayarri 2005) and by the ephemeral outlet, groundwater and evaporation outputs. Groundwater and lake waters have a similar chemistry dominated by $\mathrm{HCO}^{3-}, \mathrm{Ca}^{2+}$ and $\mathrm{Mg}^{2+}$. Analogous conductivities were measured in nearby springs (from 278 to $1420 \mu \mathrm{S} / \mathrm{cm}$ ) and lake waters (average $372 \mu \mathrm{S} / \mathrm{cm}$ ). The slight enrichment in sulphate of the lake waters relatively to the springs is coherent with shale and gypsum-rich aquifers (Bayarri 2005) and also an important role of evaporative concentration processes in the lake.

The lake is oligotrophic and meromictic with permanent oxygen-depleted conditions at the hypolimnion below $18 \mathrm{~m}$ (summer) and $20 \mathrm{~m}$ (winter) water depths, leading to high ammonium and sulphide concentrations, the latter favoured by the activity of sulphate-reducing bacteria (Camps et al. 1976). Transparency is relatively high, and $10 \%$ of light reaches up to $5 \mathrm{~m}$ water depth from November to March. The thermocline shows gradients higher than $1{ }^{\circ} \mathrm{C} / \mathrm{m}$ during summer. Alkalinity values range between 2.5 and $3.5 \mathrm{mEq} / \mathrm{l}$ and $\mathrm{pH}$ between 7 and 8.5 (Camps et al. 1976). Permanent anoxic hypolimnetic conditions favour the preservation of finely laminated sediments in central-distal areas of the lake basin, as demonstrated by short, gravity cores retrieved in 2007 and 2008. Littoral sediments are composed of massive carbonate silts with abundant plant remains and ostracods.

\section{MATERIALS AND METHODS}

Four Kullenberg cores were retrieved in May 2004 from the deepest area (30 m water depth) of the lake (Fig. 1c) using coring equipment and a platform from the Limnological Research Centre (LRC, University of Minnesota). Cores MON04-1A-1K, MON04-2A-1K and MON04-3A-1K were retrieved in a NW-SE transect in the northern part of the basin. Core MON04-4A-1K was recovered in the southern part of the deepest area of the lake. The sediment-water interphase was not preserved in these Kullenberg cores, but the uppermost part of the lacustrine sedimentary infill was recovered using gravity cores retrieved in 2007 (MON07-1A-1G, $31 \mathrm{~cm}$ long). The 
cores were split in two halves lengthwise and they were imaged with a DMT core scanner. Physical properties were measured every $5 \mathrm{~mm}$ with a Geotek multi-sensor core logger (MSCL) at the LRC. Cores were correlated using physical properties and sedimentary facies. Several gravitational deposits were identified in the cores. The MON04-1A-1K and MON04-4A-1K cores were selected to reconstruct the continuous sedimentary sequence and to carry out detailed compositional and mineralogical analysis.

The MON04-1A-1K (6.69 m long) core was sampled every $2 \mathrm{~cm}$ for total carbon (TC), total organic carbon (TOC), total sulphur (TS) and total nitrogen (TN) and every $5 \mathrm{~cm}$ for mineralogical analyses. The MON04-4A-1K (5.38 m long) core was sampled every $5 \mathrm{~cm}$ for the same analyses. The TC, TS and TOC values were analyzed by a LECO 144DR elemental analyser. TIC values were obtained substracting TOC values to the TC values. TN values were obtained with a VARIO MAX CN elemental analyser. Mineralogical analyses were carried out by X-ray diffraction (XRD), performed on an automatic X-ray diffractometer SIEMENS-D500, $\mathrm{Cu}-\mathrm{K} \alpha, 40 \mathrm{kV}, 30$ $\mathrm{mA}$ and graphite monochromator. The identification and quantification of the mineralogical species present in the crystalline fraction followed the standard procedures described in Chung (1974a, b).

Sedimentary facies were defined by visual, microscopic smear slides and thin sections observations (Schnurrenberger et al. 2003) combined with the compositional and mineralogical analyses results. Large scale thin sections $(120 \mathrm{~mm} \times 35 \mathrm{~mm})$ were prepared after freeze-drying followed by impregnation with epoxy resin (Araldite) under vacuum conditions (Brauer et al. 2000). Representative samples of the different facies were selected for morphological description and mineralogical identifications using SEM-EDS with a JEOLJSM 6400 microscope coupled with an EDX analyser working at $20 \mathrm{kV}$ and a $50^{\prime \prime}$ analysis time.

Statistical treatment of the obtained dataset (Principal Component Analysis, PCA) was carried out using R software (R Development Core Team 2008). Both magnetic susceptibility and compositional data were re-sampled every $5 \mathrm{~cm}$ in order to obtain a homogeneous database. The data, a matrix of 17 variables and 1129 cases, were normalised to eliminate the effects due to the large differences in the absolute value range of the different variables (Giralt et al. 2008). 
The chronological model of Lake Montcortès sedimentary sequence was built using a total of 17 AMS radiocarbon dates on bulk organic matter and terrestrial remains carried out at the Poznan Radiocarbon Laboratory (Poland) and the Lawrence Livermore National Laboratory (USA) (Table 1). Radiocarbon dates were calibrated using the CALPAL_A software (Weninger and Jöris 2004) and the INTCAL 04 calibration curve (Reimer et al. 2004). The age model was generated by linear interpolation of the selected ${ }^{14} \mathrm{C}$ dates using Analyseries 2.05 software (Paillard et al. 1996).

\section{RESULTS}

\section{Sedimentary Facies}

Six facies were defined in the cores: i) finely laminated (facies 1 and 2); ii) banded (facies 3); iii) graded, turbidite-like (facies 4); and iv) gravitational deposits (facies 5 and 6) (Table 1). One of the most conspicuous characteristics of the Montcortès sedimentary sequence is its finely laminated nature. In Lake Montcortès there are two types of finely laminated facies according to the presence (facies 1) or absence (facies 2) of calcite laminae. Facies 1 is composed of mm-thick triplets of three laminae: i) white layers, mostly composed of 4-20 $\mu \mathrm{m}$ long euhedral calcite crystals, ii) greenishbrownish, organic-rich laminae with abundant diatoms and amorphous organic matter and iii) grey laminae made up of carbonate, clay minerals and quartz particles of silt and clay size, nonetheless, gray laminae are not always present. Facies 1 displays intervals with thicker detrital grey laminae and more frequent deposition of intercalated massive layers, coinciding with peaks in the magnetic susceptibility (MS), and intervals showing thicker calcite laminae, thinner clastic laminae and less frequent massive clastic facies (Fig. 2).

The scarce bioturbation textures in laminated facies are indicative of limited bottom biological activity due to anoxic conditions (Brauer 2004; O'Sullivan 1983; Zolitschka 2007). In small, relatively deep karstic lakes with fluctuating lake levels these conditions occur during meromictic phases that usually correspond to relatively higher lake level periods (Brauer 2004; Martín-Puertas et al. 2009). The characteristics of these triplets suggest they represent an annual cycle in the lake deposition, with calcite formation in the epilimnion during the warmest seasons associated to algal 
blooms (spring and summer), deposition of the organic matter and diatoms during summer and fall and (brownish-greenish layer), and clastic material deposited during the rainy seasons (late fall and winter). These phenomena also occur in other lakes from the Iberian Peninsula, e.g., Zoñar Lake (Martín-Puertas et al. 2009); La Cruz lake (Julià et al. 1998; Romero-Viana 2007), and elsewhere, e.g., Piànico-Sèllere basin, (Mangili et al. 2007) and Elk lake (Anderson and Dean 1988). The intervals of facies 1 where detrital grey laminae are present are interpreted as annual (varved) deposition in a meromictic lake during periods with high clastic input to the lake during autumn and spring rains. The presence of intervals with thicker calcite and organic laminae points to periods of enhanced biological productivity in the epilimnion allowing the precipitation and preservation of endogenic calcite laminae. Facies 1 is similar to modern sediments in the deepest areas of the lake.

Facies 2 is composed of couplets of two laminae: i) mm-thick, brown to greenish, organic-rich laminae with higher content of amorphous aquatic organic matter, diatoms and clay minerals and ii) mm-thick terrigenous grey layers of silt composed by clay minerals, carbonate and quartz particles. Facies 2 has the highest TOC values (up to $18 \%$ ) in the sedimentary sequence and thicker diatom and organic matter rich laminae, suggestive of high biological productivity and organic matter preservation in the lake. However, the high $\mathrm{C} / \mathrm{N}$ ratios (up to $15.5 \%$ ) indicate a predominance of terrestrial over aquatic plants as the main source of organic matter (Meyers 2003; Meyers and Lallier-Vergès 1999), and the high clay content (66-88 \%) points to high clastic input into the lake. The absence of calcite laminae indicates that conditions were not adequate for the precipitation of calcite in the epilimnion and/or preservation in the sediments. The lake bottom and sediments could have been strongly reducing as suggested by the high organic matter and botroidal pyrite content (up to 4 $\%)$, leading to the inhibition of calcite precipitation or to its dissolution (Dean 1999). Presence of gastropods and mollusks indicate relatively shallow conditions. All these sedimentary features point to relatively shallow environmental conditions during deposition of facies 2, with high detrital and organic input from the watershed and high organic productivity in the lake.

Banded, carbonate facies 3 are composed of cm-thick greyish -brownish layers of terrigenous carbonate silty mud with organic matter, with abundant Chara and 
gastropods fragments, indicative of deposition in carbonate-producing littoral environments. Subfacies 3.1 is dominated by grey silty carbonate layers pointing to higher clastic input from the drainage basin and reworking of carbonates in the littoral platform while subfacies 3.2 is richer in organic matter.

Facies 4 occur as $\mathrm{cm}$ to $\mathrm{dm}$ - thick (up to $11.2 \mathrm{~cm}$ thick) layers, with fining upwards textures: erosive basal surfaces with plant remains, a sandy basal layer with some gypsum crystals, carbonate fragments and coarse quartz grains, and a graded layer of silt to fine mud. This facies has the highest MS values. The sedimentological features of facies 4 are characteristic of turbidite-type or storm related deposits (Noren et al. 2002). The graded nature of this facies indicates deposition by turbidite currents which separates the coarse bed load (basal term) from the fine grains in suspension (upper term). The presence of detrital irregular gypsum crystals in the record is associated to this discrete basal clastic sublayer. Principal Component Analysis (PCA) was applied to the compositional matrix (elemental, mineralogical and MS data) to objectively describe the main underlying environmental processes that have triggered the input, transport and deposition of the sedimentary particles present in the sediments (Giralt et al. 2008). The two main eigenvectors accounted for $58.75 \%$ of the total variance (Fig. 4, Table 2). The first eigenvector (PCA 1) represents the $36.2 \%$ of the total variance and it is controlled by dolomite, $\mathrm{Mg}$-calcite and quartz (Table 2) at the positive end and by TS, TOC, TN, C/N and pyrite at the negative end (Fig. 4). The association of Mg-calcite and dolomite with quartz suggests that these minerals are mainly detrital, eroded from the carbonate and evaporite of the Keuper and Muschelkalk formations outcropping in the drainage basin. The first eigenvector is likely reflecting periods of increased primary productivity (negative values) in the lake, dominant anoxic conditions in the lake bottom and early diagenetic processes leading to pyrite formation versus periods of increased clastic delivery to the lake (positive values).

The second eigenvector (PCA 2) represents the $22.55 \%$ of the total variance and it is tied by calcite and TIC at the positive end and by the magnetic susceptibility and silicates (feldspars, micas and clays) at the negative end. This eigenvector shows the opposite relationship between the deposition of distal, fine-grained siliciclastic fraction and the endogenic carbonates precipitation. 
Several $\mathrm{dm}$ to up to $3 \mathrm{~m}$ thick gravitational deposits have been identified in the Montcortès sequence. They are more abundant in the lower part of the record and the thickest gravitational deposit can be correlated in different cores. Most of them are limited by slide surfaces, and show little to null internal deformation. The facies within the gravitational deposit intervals have been assigned to the different facies identified above and they have been described according to its sedimentological characteristics, independently of its position in the allochtonous units. Only intervals with strong deformation structures have been described as gravitational deposits facies: i) facies 5 is a laminated facies with convoluted textures, folds, microfractures and slides; and ii) facies 6, a massive, chaotic heterometric deposit with abundant $\mathrm{mm}$ to $\mathrm{cm}$-long angular limestone and sandstone clasts and plant remains in a quartz-rich and silty matrix.

\section{Cores correlation and stratigraphy}

The composite sequence of the Montcortès record was constructed using the uppermost part of MON04-1A-1K core $(0-357 \mathrm{~cm})$ and the lowermost part of MON04-4A-1K core $(357-569 \mathrm{~cm})$, both close to the western margin of the basin, and the gravity short core MON07-1A-1G (Fig. 3). The Lake Montcortès sedimentary sequence has been divided into six main lithostratigraphic units (I to VI) and three allocthonous units (A, B and C) (Fig. 2).

Unit VI $(532-470 \mathrm{~cm})$ only occurs in MON04-1A-1K and MON04-4A-1K cores and it is made up of facies 2 and characterized by an upcore parallel decrease of organic carbon and clay mineral content (Fig. 3). The upper limit is gradual, defined on the basis of an increase in the abundance in endogenic calcite laminae.

Units V $(470-377 \mathrm{~cm})$, III $(109-31 \mathrm{~cm})$ and I (24-0cm, MON07-1A-1G) group variegated, finely laminated and carbonate -rich sediments (facies 1) units. In both units $\mathrm{V}$ and III, detrital layers are more abundant at the base (subunit V.c and subunit III.b) and calcite layers at the top (subunit V.a and III.a). Unit V has a $15 \mathrm{~cm}$ thick interval of facies 2 (sub-unit V.b) and several interbedded gravitational deposits in MON04-1A-1K and MON04-3A-1K cores (Fig. 2).

Units IV (377- $109 \mathrm{~cm})$ and II $(31-24 \mathrm{~cm})$ are black and grey, banded to laminated sediments (facies 1) with abundant turbidite beds (facies 4). Turbidites presence decreases from the base (subunit IV.b, $377-109 \mathrm{~cm}$ ) to the top of unit IV 
(subunit IV.a). This unit contains several gravitational deposits, present in all the cores except in MON04-3A-1K core (Fig. 2). Unit II has sharp upper and lower limits at the contact between graded facies 4 and laminated facies 1 .

The subunits with higher detrital content (units V.c, IV and II, Fig. 3) have the highest and lowest values of PCA 1 and 2 respectively. The eigenvectors show opposite behaviour in the units with higher carbonate (units I, III) and organic (unit VI) contents (Fig. 3).

Several major gravitational deposits limited by surfaces with deformation and slide structures have been identified in the Montcortès sequence (units A, B and C). The thickest ones occur in cores MON04-2A-1K and MON04-3A-1K close to the northeastern margin of the lake (Fig. 2). They are composed of littoral, banded, carbonaterich sediments (units B and C, facies 3) and may include even cm-long clasts of Triassic (Muschelkalk facies) and Tertiary (Oligocene) rocks (units A and B, facies 5 and 6). The oldest gravitational deposit occurs in MON04-4A-1K core (unit A), and includes chaotic, heterometric clastic facies with limestone and sandstone clasts. The thickest gravitational deposit (Unit C, 280cm) is located within unit IV in the MON04-2A-1K and MON04-1A-1K cores, and affected banded, carbonate-rich littoral sediments (facies 3) deposited in the north-eastern platform of the lake. The gravitational deposit registered in MON04-3A-1K core (unit B) emplaced within unit V also includes littoral, carbonate-rich sediments (facies 3) and could correlate with some of the gravitational deposits observed in MON04-1A-1K core.

\section{Age model}

The chronology of the Montcortès sequence is based on $17 \mathrm{AMS}{ }^{14} \mathrm{C}$ dates obtained in three cores (Table 3). The age model of the upper units I to IV is constrained by three dates (two from terrestrial macrorest and one from an aquatic rest) in core 1A. Since the age of the aquatic rest $\left(180 \pm 30{ }^{14} \mathrm{C} \mathrm{yr} \mathrm{BP}\right)$ is coherent with other ${ }^{14} \mathrm{C}$ dates and preliminary varve counting in unit I, the reservoir effect seems negligible in Montcortès. A sample from core 4A (unit III, $72 \mathrm{~cm}, 1290 \pm 35{ }^{14} \mathrm{C} \mathrm{yr}$ ) is too old, likely due to reworking of older lake deposits, and it has been rejected. Units V and VI have been dated in cores 1A ( 1 date) and 4A (3 dates). Four samples (charcoal, seeds and macrorest) in the base, middle and the top of the unit $\mathrm{C}$ have been dated in core $2 \mathrm{~A}$. 
Five radiocarbon dates have been obtained from unit A and they show a large range as expected due to the reworked and the alloctonous nature of this unit. However, most of the dates are between 10,500 and $6600{ }^{14} \mathrm{C}$ yr BP, suggesting that the unit includes Early to Mid Holocene sediments and that the gravitational proccess occurred during the Mid Holocene.

The age of the base of the recovered sequence has been obtained assuming a constant sedimentation rate between units V and VI. According to this chronological model, the Lake Montcortès sedimentary sequence spans the last ca. 6000 cal. yr BP and the oldest "in situ" deposits are those in unit VI of core 4A (Fig. 5). The sedimentation rate is relatively low in units V and VI $(0.03 \mathrm{~cm} / \mathrm{yr})$, increasing tenfold times up to $0.31 \mathrm{~cm} / \mathrm{yr}$ during the last $1300 \mathrm{yrs}$. This increase in the sedimentation rate correlates with a change in the sedimentary facies and higher frequency of turbidite events (facies 4 and 5). The emplacement of unit A would have occurred prior to 6000 cal. yr BP. Unit B was emplaced during the early deposition of Unit V (around $1600 \mathrm{cal}$. yr BP). Unit C records sedimentation in the littoral northeastern margin of the lake from ca. 7500 to 1640 cal. yr BP. Littoral sedimentation rate displays a similar trend than distal deposits. It shows a lower sedimentation rate during the 7490-1830 cal. yr BP interval $(0.03 \mathrm{~cm} / \mathrm{yr})$ and an abrupt increase from $1830 \mathrm{cal}$. yr BP $(0.45 \mathrm{~cm} / \mathrm{yr})$. Based on the detailed correlation between cores $1 \mathrm{~A}$ and $2 \mathrm{~A}$, the gravitational deposit that transported these littoral materials to the deep areas of the lake occurred during deposition of unit IV, just after approximately 1000 cal. yr BP (Fig. 2).

\section{DISCUSSION}

\section{Depositional Evolution of Montcortès Lake}

Four main depositional stages have been interpreted during the last $6000 \mathrm{cal}$. yr BP in the Lake Montcortès based on sedimentary facies analyses and core correlation (Fig. 6):

Early Holocene (prior to 6000 cal. yr BP, unit A): Gravitational process affecting littoral lacustrine and alluvial/colluvial sediments

Prior to 6000 cal. yr BP, a gravitational process involving lacustrine sediments and some coarse clastic materials of alluvial or littoral origin was emplaced in the southern end of the lake (unit A). Although the sediments are reworked and depositional textures 
and structures are not easily recognizable, the clastic nature of the facies -high silicate content (68-96\%), large clasts- suggest that the sediments had been originally deposited in a littoral, shallow lacustrine setting with a large alluvial influence.

Mid Holocene (6000 - 3800 cal. yr BP; 4090 - 1850 BC; Unit VI): relatively shallow, meromictic lake with a carbonate platform and associated palustrine subenvironments

Finely laminated facies 2 covered Unit A suggesting the presence of anoxic environments in the lake bottom where the gravitational deposit was emplaced. Finely lamination and development of diatom-rich and organic rich laminae suggest high primary productivity in a lake with high preservation potential in the anoxic western and southern deep areas of the lake (Unit VI, core 4A: 500-438cm, core 1A: 670-600 cm). Furthermore, organic matter accumulation decreased progressively reaching a minimum at the end of this stage. Intervals with thicker and more frequent clastic laminae define periods of higher sediment delivery to the lake. There are some evidences that point to a relatively shallow depositional environment: i) A high $\mathrm{C} / \mathrm{N}$ ratio, indicative of higher terrestrial plants input than lacustrine organic matter (Meyers and Lallier-Vergès 1999; Meyers 2003); ii) the abundance of typical littoral biota, like gastropods and ostracods: iii) the presence of some layers composed of reworked lacustrine carbonate indicating the proximity of the littoral platform.

Although there are no calcite laminae in facies 2, carbonate productivity was very high in the northeastern littoral shelf, as banded, carbonate facies 3 deposited during this period (Unit C). The nature of facies 3 with abundant Chara fragments demonstrates the large development of a carbonate shelf during the Holocene in the NE margin of Montcortès Lake. This platform was likely the source of the carbonate particles that reached the deepest areas and intercalated within facies 2 . The large development of charophyte meadows would have also acted as a barrier for coarse sediments, allowing the sedimentation of fine-grained particles and favouring the enrichment in clay mineral content of facies 2 . The absence of carbonate laminae in deeper environments is coherent with high organic matter accumulation leading to lower $\mathrm{pH}$ of anoxic pore waters enough to dissolve $\mathrm{CaCO}_{3}$ particles reaching sedimentwater interface (Dean 1999). 
Therefore, Mid Holocene depositional environments in Lake Montcortès included a well-developed carbonate littoral shelf in the NE margin (facies 3.2), relatively deeper anoxic environments in the central and western areas dominated by organic and fine clastic deposition (facies 2) and likely, a shallower, wetland area to the SW that could have been the source of organic matter to laminated facies 2 and also act as filter for coarse clastic particles.

Late Holocene to Medieval Age (3800 - 1260 cal. yr BP; 1850 BC - 690 AD; Unit V): Deep, meromictic, carbonate-producing lake with high primary productivity

Higher lake levels, meromictic conditions and a gradual increase in the biological productivity of the lake with deposition of varved facies 1 prevailed in Montcortès Lake from 3800 to $1260 \mathrm{cal}$. yr BP. Three periods can be differentiated according to the dominance of facies 1 (with endogenic calcite laminae) or 2 (without). During a first phase (3800- 2350 cal. yr BP; 1850 BC- 400 BC, subunit V.c) thicker and frequent clastic grey laminae indicate an increase in the catchment runoff and sediment input to the lake that could have paralleled a lake level increase. The deposition of a $15 \mathrm{~cm}$ thick brown, organic- rich interval (facies 2) (2350- 1910 cal. yr BP; 400 BC- 40 AD, subunit V.b) suggests a transition to similar depositional environments of unit VI, and likely a lower lake level. Finally, during the last phase of this stage (subunit V.a, 1910- 1260 cal. yr BP; 40- 690 AD), varves with calcite, organic and occasionally detrital laminae deposited (facies 1), and calcite layers were particularly well developed. Formation of calcite may respond primarily to annual changes in the biological productivity (Kelts and Hsü 1978) probably due to seasonal algal blooms as it has been widely described elsewhere (Romero-Viana et al. 2008). Primary productivity was also high, as indicated by the high organic content (with values up to 8.2\%) and the $\mathrm{C} / \mathrm{N}$ ratio (Fig. 3) more typical of lacustrine organic matter. The relation between algal activity and calcite precipitation has been documented in SEM images with monospecific diatoms laminae, mostly composed of predominantly central, planktonic specimens (mainly Cyclotella spp., Scussolini, pers. comm.), associated to the calcite laminae. The paleolimnological conditions interpreted for this period of calcite formation (subunit V.a) would be similar to those of current times in the lake: relatively high lake levels, high carbonate and calcium input from the aquifers and surface waters, low sediment delivery and a progressive increase in the lake primary productivity in the epilimnion. 
Unit V shows several interbedded gravitational deposits in MON04-1A-1K, MON04$2 \mathrm{~A}-1 \mathrm{~K}$ and MON04-3A-1K cores. However, the largest gravitational deposit along the sedimentary record (Unit C) can be found within unit IV in the MON04-2A-1K (545$265 \mathrm{~cm})$ and MON04-1A-1K (388- $432 \mathrm{~cm})$ cores. This gravitational process affected Mid to Late Holocene carbonate-rich littoral sediments deposited in the north-eastern platform of the lake between 7490 to $1640 \mathrm{cal}$. yr BP. The gravitational slide occurred ca. $1010 \mathrm{yr}$ BP (940 AD). In the carbonate shelf (recovered in unit C), the onset of this stage at 3800 cal. yr BP corresponds with an abrupt increase in the detrital input and a change to the deposition of more clastic, banded, carbonate facies 3.1. After this period, sedimentation in the platform, however, remained carbonate-rich, similar to previous stages.

The gravitational deposit registered in MON04-3A-1K core (unit B) also includes littoral, carbonate-rich sediments and could correlate with some of the gravitational deposits observed in the lower part of MON04-1A-1K core. Seismicallyinduced structures like liquefaction levels or fault graded beds (Rodríguez-Pascua et al. 2003) have been observed. The origin of these gravitational deposits was also likely the northern margin of the lake. The relative chronology also indicates that this gravitational process occurred prior to 1600 cal. yr BP. Submerged, sediment-laden slopes instability occurs both in lacustrine environments, triggered by erosion increase, high sedimentation rates, gas release or migration, seismic events or hydrological fluctuations (Hampton et al. 1996; Locat and Lee 2002; Strasser et al. 2007). In the case of Lake Montcortès, rapid lake level fluctuations are unlikely during this period, since the hydrological balance was controlled by the location of the outlet and no rapid changes of facies were detected.

\section{Last 1300 years: Deep, meromictic lake with high alternating phases of high clastic input and high carbonate productivity}

The onset of this period is gradual, starting with deposition of subfacies 1.1 and an increase in silicate mineral content. During the first stage corresponding to the Medieval Ages (1260 - 490 cal. yr BP; 690 - 1460 AD; Unit IV), laminated facies 1 deposited with frequent intercalations of turbidites (facies 4). The high turbidite frequency and the occurrence of the highest sedimentation rate in the whole sequence $(3.1 \mathrm{~mm} / \mathrm{yr})$ indicate an increase in sediment delivery to the lake. The frequency of turbidites greatly 
increased afterwards during deposition of unit IV.a, and up to 490 cal yr BP (1460 AD). The turbidite layers in Montcortès Lake may correspond to single events characterized by a rapid influx of terrigenous sediments transported by increased water runoff from the watershed.

An abrupt decrease in the clastic input inaugurated the following phase (490180 cal. yr BP; 1460-1770 AD) dominated by deposition of variegated, finely laminated carbonated subfacies 1.2 (unit III; Fig. 3), indicative of higher endogenic calcite formation and organic bioproductivity, especially during the last depositional stage (unit III.a). Clastic input slightly increased after 280 cal. yr BP (1660 AD) (Subunit III a), but the large limnological change occurred at about 180 cal. yr BP (1770 AD) when turbidite processes dominated deposition in the central areas of the lake with fining upward sequences of facies 4 and high MS values (Unit II). The sedimentation rate increased again as occurred in unit IV. The presence of gypsum associated to the detrital layers suggests reworking of littoral sediments or evaporite-bearing formations in the watershed. This period of increased clastic input continued during the $19^{\text {th }}$ century. During the $20^{\text {th }}$ century sedimentation of facies 1 with reduced clastic input resumed (Unit I). Current depositional environments in Montcortès (unit I) are similar to those represented by subunits III.b and V.a. with precipitation of endogenic carbonates during warm seasons associated to algal blooms and meromictic conditions.

\section{Climate variability and Human Impact}

The Montcortès record provides a remarkable example of the synergic effects of climate and human activities in Mediterranean mountain areas (Fig. 6). During the Mid Holocene (6000 -3800 cal. years BP; 4090- 1490 BC) comparatively shallower lake levels than during the Late Holocene occurred in Montcortès Lake. Most lacustrine (Pérez-Obiol and Julià 1994; Davis 1994; Pons and Reille 1988; Yll et al. 1997; Reed et al. 2001; Carrión et al. 2003; González-Sampériz et al. 2008; Morellón et al. 2008) and fluvial (Benito et al. 1996) records in the Iberian Peninsula show evidences of increased aridity in the Mid Holocene compared to relatively more humid Early and Late Holocene. The nearby Estanya Lake shows a similar behaviour during this period, with a development of a saline gypsum-rich lake, punctuated by periods of higher clastic delivery into the lake (Morellón et al. 2008). The nearby record of Estany Redon shows a warming trend from the Early Holocene to 4 kyr BP (Pla and Catalan 2005) (Fig. 6) 
and relatively lower lake levels occurred in Lake Estanya during the Mid Holocene (Morellón et al. 2008). The onset of this period of higher aridity in the Iberian Peninsula at around 6 ka correlates with similar changes in the Alps (Magny 2006) and in northern Africa with the end of the African Humid Period (Gasse and Van Campo 1994; deMenocal et al. 2000; Kropelin et al. 2008) and reflects a decrease of solar radiation in summer in the northern hemisphere.

A significant limnological change occurred in Montcortès at about 3800 cal. yr BP (1850 BC) when endogenic calcite precipitated in the epilimnion was preserved in the sediments and varves composed of three laminae deposited. This change coincides with the onset of the humidity increase inferred for the Mediterranean area (Roca and Julià 1997; Sadori et al. 2004; Martín-Puertas et al. 2008, 2009) after the aridity crises of the $4.2 \mathrm{ka}$ (Cullen et al. 2000; Arz et al. 2006; Drysdale et al. 2006) and also correspond to the cold and wet phase of the Iron Age in northern Europe (Leira 2005) between 3000 and 2000 cal. yr BP (1050- 50 BC). The Spanish fluvial record shows a floodplain aggradation stage at 2710-2320 cal. yr BP in phase with the timing of slackwater flood deposition (2865-2350 cal. yr BP) (Benito et al. 2008). The likely Montcortès lake level drop between 2350 and 1910 cal. yr BP (400 BC- 40 AD) coincides with a reduction in the river floods frequency in the Iberian Peninsula (Macklin et al. 2006) between 2350 and 2000 cal. yr BP and lower lake levels in Zoñar lake between 2100 and 1900 cal. yr BP (Martín-Puertas et al. 2008).

The Iberian-Roman Humid Period (500 BC - 400 AD) is well defined in southern Spain (Zoñar Lake, Martín Puertas et al. 2008) where it is the most humid phase during the last 4000 years. However in the available lake records from northern Spain as Estanya lake (Morellón et al. 2008) and Estany Redon (Pla and Catalán 2005) the paleohydrological signal is not so clear. After 1900 cal. yr BP (50 AD), varves with endogenic calcite dominated in Montcortès until present day indicating that lake level remained relatively high, controlled by the location of the outlet. This change correlates with an increase in lake level during the last 2000 years observed in other records from nearby lakes as Estanya lake (Morellón et al. 2008) in the Pre-Pyrenees or La Playa and La Salineta lakes (González-Sampériz et al. 2008) in the Ebro basin. The onset of this humidity increase coincides with the beginning of the Classic Roman Period that has been documented as a humid period in the Mediterranean area (Reale and Dirmeyer 
2000) and with a second humid phase in the Zoñar Lake record (Martín Puertas et al., 2008).

The period 1260 - 490 cal. yr BP (690 AD - 1460 AD), with high clastic input in Montcortès Lake, coincides with the Medieval Climate Anomaly (MCA), a relatively warm and arid period in the Northern Hemisphere (Seager et al. 2007) that has been related to increase global irradiance (Bard et al. 2000). During this period, several lake Spanish records show evidences of aridity: in the south (Zoñar lake, between 1350 and 730 cal. yr BP (600-1220 AD) (Martín-Puertas et al. 2008), in the Pyrenees - Estanya, between 950 and 800 cal. yr BP (1000- 1150 AD) (Morellón et al. 2008) and in the Iberian Range, - La Cruz Lake (Julià et al. 1998), Taravilla Lake (Moreno et al. 2008; Valero-Garcés et al. 2008)-. Likewise, there is an aridity increase during this period in Central Italy lakes (Dragoni 1998) and northern Africa (Lamb et al. 1995) and a decrease in the mean precipitation inferred in Soreq Cave record (Israel) (Bar-Matthews et al. 1999) (Fig. 6).

The increase in sediment delivery to the lakes in N Spain during the Medieval period may be related to: i) changes in land use due to increase in farming practices owing to higher population during the Muslim periods and the subsequent Christian conquest (Salrach 1995) (Fig. 6) or, ii) to climatic factors, such as the loss of vegetative ground cover associated with decreased precipitation, and development of larger littoral environments in the lake, or, iii) a synergic interaction between both anthropic and climate factors. The onset of this period coincides with the Muslim Conquest of the region, $\left(7^{\text {th }}\right.$ century) which brought a higher regional development of farming practices, with new irrigation techniques, particularly in the valleys. During medieval times, the Pyrenees and the southern slopes where Montcortès Lake is located, experienced an increase in population as a result of the migration of people escaping from the northward Muslim expansion and the state of more continuous warfare in the lowlands. Once the Christian Kingdoms were firmly established, fire was a common agriculture practice to prepare the land for shifting cultivation, and forests were intensively used. During the $10^{\text {th }}$ century, coinciding with the onset of subunit IV.b deposits, a more controlled and planned land exploitation was established, using livestock for ploughing and as a fertilizer source, and rivers margins and wetlands were preferred places for this type of mixed farming (Esteban 2003; Marugan and Oliver 2005). Thus, the high 
sedimentation rate of unit IV may be the result of the combination of climatic factors (increase in high intensity storm events, relatively lower lake levels, more development of littoral environments) and changes in land use with deforestation and farming causing an increase in runoff and deposition of clastic material by turbiditic currents. This phenomenon has been documented in other similar Spanish karstic lakes: Arreo and Estanya lakes (Morellón et al. 2008) in the Pre-Pyrenees, Taravilla lake (ValeroGarcés et al. 2008) in the Iberian Range, and Zoñar lake in Andalusia (Martín-Puertas et al. 2008). Floodplain aggradation in Iberian rivers from 910 to 500 cal. yr BP (Benito et al. 2008) also suggests an increase of agriculture and deforestation.

The reduction of clastic input, higher primary productivity, and enhanced endogenic calcite precipitation in Montcortès Lake between 488 and 177 cal. yr BP (1462- $1773 \mathrm{AD}$ ) coincides with the onset and the first phases of the Little Ice Age (LIA), a humid and cold period in Europe (Grove 1988; Porter 1986; Starkel 1991; Pfister et al. 1998). In Spain, this period is characterized by higher river floods frequency between 520 and 265 cal. yr BP (1430- 1685 AD) (Thorndycraft and Benito 2006) and higher lake levels in different sedimentary records from the Iberian Peninsula, e.g. La Cruz lake (Julià et al. 1998), Taravilla lake (Valero-Garcés et al. 2008), Zoñar lake (Martín-Puertas et al. 2008), Estanya lake (Morellón et al. 2008). In one karstic lake (La Cruz), palynological studies have shown a relation between increasing farming lands (and a subsequent forest areas decrease) and cooler temperatures and higher lake level with development of lacustrine varves (Julià et al. 1998). Nevertheless, the reduction of clastic input recognized in the Montcortès Lake for this period may also be related to the economic and social crisis during $14^{\text {th }}$ and $15^{\text {th }}$ centuries coinciding with the "Black Death" epidemics (AD 1348) and wars (AD 14841487) which caused a significant depopulation of the area with the consequent abandonment of their respective lands, crops, pastures and natural resources (Marugan and Oliver 2005).

The increase in turbiditic current frequency in Montcortès during the $19^{\text {th }}$ century coincides with the last phases of the LIA and the maximum expansion of agriculture and population in the Pyrenean Mountains (Fillat et al. 2008). During this pre-industrial period traditional crop rotation was used to enhance cereal production. Forest exploitation was the dominant practices in the mountains. In the historical record, 
the AD 1760-1800 period was noteworthy for strong climatic variability with floods and droughts occurring in the Spanish Mediterranean area (Barriendos and Llasat 2003). In Northeast Spain, documentary sources also indicate highest flood severity during AD 1840-1870 (Llasat et al. 2003). Thus, this period of increased clastic input during the $19^{\text {th }}$ century would be triggered to both climatic (more intense phases of the LIA) and anthropic causes (Morellón et al, in press-a).

Recent $\left(20^{\text {th }}\right.$ century) and present-day increase in the lake bioproductivity may be influenced by reduced sediment delivery to the lake and increased nutrients due a more intensive use of the lake for tourism activities and fertilizers and pollutants. This would entail nutrients inputs contributing to the lake eutrophication. An example of recent development of lacustrine varves from $1885 \mathrm{AD}$ due to an eutrophication process occurred in Baldeggersee (Switzerland) (Fabian et al. 2003). The recent reduction of clastic input may be related to the emigration from rural zones to urban industrialized areas which profoundly affected the Pallars region between 1960- 1980 AD (Farràs 2005). Recent varve formation in Lake Montcortès could have been favoured by the synergetic effect of: i) decreased turbidite floods frequency due to lower sediment delivery caused by lower human impact in the watershed, ii) warmer temperatures during the last decades, iii) increase in fertilizers input and consequent enhanced lake primary productivity.

\section{CONCLUSIONS}

The changing nature of the finely laminated facies in the Montcortès Lake sedimentary sequence record the interplay between climate and human factors in the lake and the watershed for the last $6000 \mathrm{cal}$. years BP. Anoxic bottom conditions prevailed during this period and varves composed of triplets (calcite, organic, clastic laminae) or couplets (organic, clastic laminae) with some turbidite layers deposited in the deepest areas of the lake.

Carbonate production and preservation coincided with periods of increased bioproductivity, and likely higher lake levels. Periods with no endogenic carbonate preservation are related to relatively lower lake levels and high organic matter accumulation in the deeper areas. According to the chronological model and detailed sedimentary facies analyses, relatively shallower lake levels with no carbonate 
production occurred during the period 6000 - $3800 \mathrm{cal}$. yr BP, synchronous to the Mid Holocene arid period in the Iberian Peninsula. The transition to deeper lake conditions and the onset of carbonate production at the epilimnion started at $3800 \mathrm{cal}$ yr BP and continued until the present. Periods of lower clastic input into the lake occurred during the Iberian-Roman Humid Period, the Little Ice Age (LIA) and the last 50 years. In contrast, periods of increased sediment delivery to the lake from the watershed occurred during the Middle Ages, synchronous to the Medieval Climate Anomaly and the $19^{\text {th }}$ century coinciding with drier conditions and higher human pressure over the land.

Although it could be modulated by climate and hydrological variability, changes in the clastic input to the lake reflects modifications in the agricultural practices and population pressure and their subsequent impact in the watershed. Several turbidite deposits punctuates the sequence, reaching their higher frequency coinciding with two periods of intense human impact in the watershed: i) the Medieval Ages (690-1460 AD), including the Muslim Period and the Christian Conquest and synchronous to the Medieval Climate Anomaly; and ii) the $19^{\text {th }}$ century, corresponding to the last phases of the LIA and the period with the maximum occupation of the territory.

Three major gravitational processes phases in the lake have been identified in the lower part of the sedimentary record affecting carbonate-rich littoral sediments and/or allochtonous sediments from the drainage basin. They occurred around 1010, 1600 and 6000 cal. yr BP.

\section{AKNOWLEDGMENTS}

Financial support for this research was provided by the Spanish Inter-Ministry of Science and Technology (CICYT), through the projects LIMNOCLIBER (REN200309130-C02-02), IBERLIMNO (CGL2005-20236-E/CLI), LIMNOCAL (CGL200613327-C04-01) and GRACCIE (CSD2007-00067). Additional funding was provided by the Aragonese Regional Government-CAJA INMACULADA which partially funded the microfacies analysis at GFZ (Potsdam) by means of one travel grant. Juan Pablo Corella is supported by a $\mathrm{PhD}$ contract paid by the CONAI+D (Aragonese Scientific Council for Research and Development), A. Moreno holds a Ramón y Cajal programme post-doctoral contract, M. Rico holds a Juan de la Cierva contract from the Spanish 
Government and A. Pérez-Sanz holds a CONAI+D PhD fellowship. We are indebted to GFZ and IPE-CSIC laboratory staff for their collaboration in this research. 


\section{REFERENCES}

Allen JRM, Huntley B and Watts WA (1996) The vegetation and climate of northwest Iberia over the last 14,000 years. Journal of Quaternary Science 11: 125-147

Anderson R and Dean W (1988) Lacustrine varve formation trough time. Palaeogeography, Palaeoclimatology, Palaeoecology 62: 215-235

Arz HW, Lamy F and Pätzold J (2006) A pronounced dry event recorded around 4.2 ka in brine sediments from the northern Red Sea. Quaternary Research 66: 432-441

Bar-Matthews M, Ayalon A, Kaufman A and Wasserburg GJ (1999) The eastern Mediterranean paleoclimate as a reflection of regional events: Soreq cave, Israel. Earth and Planetary Science Letters 166: $85-95$

Bar-Matthews M, Ayalon A, Gilmour MA, Matthews A and Hawkesworth CJ (2003) Sea-land oxygen isotopic relationships from planktonic foraminifera and speleothems in the Eastern Mediterranean region and their implication for paleorainfall during interglacial intervals. Geochimica et Cosmochimica Acta 67: 3181-3199

Bard E, Raisbeck G, Yiou F and Jouzel J (2000) Solar irradiance during the last 1200 yr based on cosmogenic nuclides. Tellus 52B: 985-992

Barriendos M and Llasat MC (2003) The Case of the 'Maldá' Anomaly in the Western Mediterranean Basin (AD 1760-1800): an example of a strong climatic variability. Climatic Change 61: 191-216

Bayarri J (2005) Origen de les aigües del llac de Montcortès (Baix Pallars, Lleida). Treball de fi de carrera. Universitat de Barcelona, Barcelona

Benito G, Machado MJ and Pérez-González A (1996) Climate change and flood sensitivity in Spain. In: J. Branson, A. G. Brown and K. J. Gregory (eds.), Global continental changes: the context of paleohydrology. The Geological Society of London, London, pp 85-98

Benito G, Thorndycraft VR, Rico M, Sánchez-Moya Y and Sopeña A (2008) Palaeoflood and floodplain records from Spain: Evidence for long-term climate variability and environmental changes. Geomorphology 101: 68-77

Blanco E, Casado M, Costa M, Escribano R, García Antón M, Génova M, Gómez A, Moreno J, Morla C, Regato P and Sainz Ollero H (1997) Los Bosques Ibéricos. Una Interpretación Geobotánica. Planeta, Barcelona, pp 572 
Bond G, Showers W, Cheseby M, Lotti R, Almasi P, de Menocal P, Priore P, Cullen H, Hajdas I and Bonani G (1997) A pervasive millenial-scale cycle in North Atlantic Holocene and glacial climates. Science 278: 1257-1266

Bond G, Kromer B, Beer J, Muscheler R, Evans MN, Showers W, Hoffmann S, Lotti-Bond R, Hajdas I and Bonani G (2001) Persistent solar influence on north Atlantic climate during the Holocene. Science 294: $2130-2136$

Brauer A, Mingram J, Frank U, Gunter C, Schettler G, Wulf S, Zolitschka B and Negendank JFW (2000) Abrupt environmental oscillations during the Early Weichselian recorded at Lago Grande di Monticchio, southern Italy. Quaternary International 73-4: 79-90

Brauer A (2004) Annually laminated lake sediments and their palaeoclimatic relevance. Springer, 109. pp 128

Camps J, Gonzalvo I, Güell J, López P, Tejero A, Toldrà X, Vallespinos F and Vicens M (1976) El lago de Montcortès, descripción de un ciclo anual. Oecología acuática 2: 99-100

Canals M, Got H, Julia R and Serra J (1990) Solution-collapse depressions and suspensates in the limnocrenic lake of Banyoles (NE Spain). Earth Surface Processes and Landforms 15: 243-254

Carrion JS, Sanchez-Gomez P, Mota JF, Yll R and Chain C (2003) Holocene vegetation dynamics, fire and grazing in the Sierra de Gador, southern Spain. Holocene 13: 839-849

Cohen AS (2003) Paleolimnology. The history and evolution of lake systems. Oxford University Press, New York, pp 500

Cristina XP, Vila X, Abella CA and Bañeras L (2000) Anoxygenic phototrophic sulfur bacteria in Montcortès Lake (Spain): the deepest population of Chromatium sp. Verh Internat Verein Limnol 27: 854-858

Cullen H, deMenocal P, Hemming SR, Brown FH, Guilderson TP and Sirocko F (2000) Climate change and the collapse of the Akkadian empire: evidence from the deep sea. Geology 28: 379-382

Chung FH (1974a) Quantitative interpretation of X-ray diffraction patterns of mixtures: I. Matrix-flushing method for quantitative multicomponent analysis. Journal of Applied Crystallography 7: 519-525

Chung FH (1974b) Quantitative interpretation of X-ray diffraction patterns of mixtures: II. Adiabatic principles of X-ray diffraction analysis of mixtures. Journal of Applied Crystallography 7: 526-531

Davis BAS (1994) Palaeolimnology and Holocene environmental change from endorheic lakes in the Ebro Basin, North-East Spain. Ph.D. University of Newcastle Upon Tyne, UK 
Dean W (1999) The carbon cycle and biochemical dynamics in lake sediments. Journal of Paleolimnology 21: 375-393

deMenocal P, Ortiz J, Guilderson T, Adkins J, Sarnthein M, Baker L and Yarusinsky M (2000) Abrupt onset and termination of the African Humid Period: rapid climate responses to gradual insolation forcing. Quaternary Science Reviews 19: 347-361

Dragoni W (1998) Some consideration on climate changes, water resources and water needs in the Italian region south of $43^{\circ}$ N. In: N. a. B. Issar (ed.), Water, Environment and Society in Times of Climate Change. Kluwe Academic, Dordrech, pp 241-272

Drysdale R, Zanchetta G, Hellstrom J, Maas R, Fallick A, Pickett M, Cartwright I and Piccini L (2006) Late Holocene drought responsible for the collapse of Old World civilizations is recorded in an Italian cave flowstone. Geology 34: 101-104.

Esteban-Amat E (2003) La humanización de las altas cuencas de la Garona y las Nogueras (4500 aC 1955 dC). Ministerio de Medio Ambiente, Secretaría General de Medio Ambiente, Madrid

Fabian D, Zhou Z, Wehrli B and Friedl G (2003) Diagenetic cycling of arsenic in the sediments of eutrophic Baldeggersee, Switzerland. Applied Geochemistry 18: 1497-1506

Farràs F (2005) El Pallars contemporani. In: C. M. R. Marguan, V. (eds,), Història del Pallars Dels orígens als nostre dies, Lleida, pp 121-144

Fillat F, García-González R, Gómez D and Reiné R (2008) Pastos del Pirineo. Consejo Superior de Investigaciones Científicas (C.S.I.C), Madrid, Spain, pp 319

Gasse F and Van Campo E (1994) Abrupt post-glacial climate events in West Asia and North Africa monsoon domains. Earth and Planetary Science Letters 126: 435-456

Giralt S, Burjachs F, Roca JR and Julia R (1999) Late Glacial to Early Holocene environmental adjustment in the Mediterranean semi-arid zone of the Salines playa-lake (Alacant, Spain). Journal of Paleolimnology 21: 449-460

Giralt S, Moreno A, Valero-Garcés B, Sáez A, Bao R, Prego R, Pueyo JJ, González-Sampériz P and Taberner C (2008) A statistical approach to disentangle environmental forcings in a lacustrine record: the Lago Chungará case (Chilean Altiplano). Journal of Paleolimnology 40: 195-215

González-Sampériz P, Valero-Garcés BL, Carrión JS, Peña-Monné JL, García-Ruiz JM and Martí-Bono C (2005) Glacial and Lateglacial vegetation in northeastern Spain: New data and a review. Quaternary International 140-141: 4-20

González-Sampériz P, Valero-Garcés BL, Moreno A, Morellon M, Navas A, Machin J and DelgadoHuertas A (2008) Vegetation changes and hydrological fluctuations in the Central Ebro Basin (NE Spain) 
since the Late Glacial period: saline lake records. Palaeogeography, Palaeoclimatology, Palaeoecology 259: $136-115$

Grove JM (1988) The Little Ice Age. New York, NY (US) ;Routledge, Chapman and Hall, United States, pp 498

Gutiérrez F, Calaforra J, Cardona F, Ortí F, Durán J and Garay P (2008) Geological and environmental implications of the evaporite karst in Spain. Environmental Geology 53: 951-965

Hampton MA, Lee HJ and Locat J (1996) Submarine landslides. Reviews of Geophysics 34: 33-59

Julià R, Burjachs F, Dasí MJ, Mezquita F, Miracle RM, Roca JR, Seret G and Vicente E (1998) Meromixis origin and recent trophic evolution in the Spanish mountain lake La Cruz. Aquatic Sciences 60: $279-299$

Kelts K and Hsü KJ (1978) Freshwater carbonate sedimentation. In: A. Lerman (ed.), Lakes-chemistry, geology, physics. Springer Verlag, Berlin, Heidelberg, pp 295-323

Kropelin S, Verschuren D, Lezine AM, Eggermont H, Cocquyt C, Francus P, Cazet JP, Fagot M, Rumes B, Russell JM, Darius F, Conley DJ, Schuster M, von Suchodoletz H and Engstrom DR (2008) ClimateDriven Ecosystem Succession in the Sahara: The Past 6000 Years. Science 320: 765-768

Lamb H, Gasse F, Benkaddour A, El Hamoutl N, Van der Kaars S, Perkins WT, Pearce NJ and Roberts CN (1995) Relation between century-scale Holocene arid intervals in tropical and temperate zones. Nature 373: 134-137

Leira M (2005) Diatom responses to Holocene environmental changes in a small lake in northwest Spain. Quaternary International 140: 90-102

Liu Z, Wang Y, Gallimore R, Notaro M and Prentice IC (2006) On the cause of abrupt vegetation collapse in North Africa during the Holocene: Climate variability vs. vegetation feedback. Geophys Res Lett 33; L22709, doi:10.1029/2006GL028062.

Locat J and Lee HJ (2002) Submarine landslides: advances and challenges. Canadian Geotechnical Journal 39: 193-212

Luque JA and Julià R (2002) Lake sediment response to land-use and climate change during the last 1000 years in the oligotrophic Lake Sanabria (northwest of Iberian Peninsula). Sedimentary Geology 148: 343355

Llasat MC, Rigo T and Barriendos M (2003) The "Montserrat-2000" flash-flood event: a comparison with the floods that have occurred in the northeastern Iberian peninsula since the 14th century. International Journal of Climatology 23: 453-469 
Macklin MG, Benito G, Gregory KJ, Johnstone E, Lewin J, Michczyñska DJ, Soja R, Starkel L and Thorndycraft VR (2006) Past hydrological events reflected in the Holocene fluvial record of Europe. Catena 66: 145-154

Magny M (2006) Holocene fluctuations of lake levels in west-central Europe: methods of reconstruction, regional pattern, palaeoclimatic significance and forcing factors. In: S. A. Elias (ed.), Encyclopedia of Quaternary geology Encyclopedia of Quaternary Science. Elsevier

Mangili C, Brauer A, Plessen B and Moscariello A (2007) Centennial-scale oscillations in oxygen and carbon isotopes of endogenic calcite from a 15,500 varve year record of the Piànico interglacial. Quaternary Science Reviews 26: 1725-1735

Martín-Puertas C, Valero-Garcés BL, Mata P, González-Sampériz P, Bao R, Moreno A and Stefanova V 2008. Arid and Humid Phases in Southern Spain during the last 4000 Years: The Zoñar Lake Record, Córdoba. The Holocene 18: 907-921

Martín-Puertas C, Valero-Garcés BL, Brauer A, Mata MP, Delgado-Huertas A and Dulski P (2009) The Iberian-Roman Humid Period (2600-1600 cal yr BP) in the Zoñar Lake varve record (Andalucía, southern Spain). Quaternary Research 71: 108-120

Marugan CM and Oliver J (2005) El Pallars medieval. In: C. M. R. Marguan, V. (eds,), Història del Pallars Dels orígens als nostre dies. Pagès Editors, Lleida, pp 45-86

Meyers PA and Lallier-Vergès E (1999) Lacustrine Sedimentary Organic Matter Records of Late Quaternary Paleoclimates. Journal of Paleolimnology 21: 345

Meyers PA (2003) Applications of organic geochemistry to paleolimnological reconstructions: a summary of examples from the Laurentian Great Lakes. Organic Geochemistry 34: 261-289

Miracle MR and Gonzalvo I (1979) Els llacs càrstics. Quad Ecol Apl 4: $37-50$

Miracle MR, Vicente E and Pedrós-Alió C (1992) Biological studies of spanish meromictic and stratified karstic lakes. Limnetica 8: 59-77

Modamio X, Peres V and Samarra F (1988) Limnology of the Montcortes Lake (1978-79 Cycle) (Limnologia del Lago de Montcores (Ciclo 1978-79) (Pallars Jussa, Lleida)) Oecologia Aquatica Vol. 9: $9-17$

Morellón M, Valero-Garcés B, Moreno A, González-Sampériz P, Mata P, Romero O, Maestro M and Navas A (2008) Holocene palaeohydrology and climate variability in northeastern Spain: The sedimentary record of Lake Estanya (Pre-Pyrenean range). Quaternary International 181: 15-31 
Morellón M, Valero-Garcés BL, Anselmetti F, Ariztegui D, Schnellmann M, Moreno A, Mata P, Rico M and Corella JP (2009) Late Quaternary deposition and facies model for karstic Lake Estanya (NE Spain). Sedimentology 56: 1505-1534

Morellón M, Valero-Garcés BL, González-Sampériz P, Vegas-Vilarrúbia T, Rubio E, Rieradevall M, Delgado-Huertas A, Mata P, Romero Ó, Engstrom DR, López-Vicente M, Navas A and Soto J (In pressa) Climate changes and human activities recorded in the sediments of Lake Estanya (NE Spain) during the Medieval Warm Period and Little Ice Age. Journal of Paleolimnology: doi: 101007/s10933-009-93463

Morellón M, Valero-Garcés BL, Vegas-Vilarrúbia T, González-Sampériz P, Romero Ó, Delgado-Huertas A, Mata P, Moreno A, Rico M and Corella JP (In press-b) Lateglacial and Holocene palaeohydrology in the western Mediterranean region: The Lake Estanya record (NE Spain). Quaternary Science Reviews: doi:10.1016/j.quascirev.2009.05.014

Moreno A, Valero-Garcés BL, González-Sampériz P and Rico M (2008) Flood response to rainfall variability during the last 2000 years inferred from the Taravilla Lake record (Central Iberian Range, Spain). Journal of Paleolimnology 40: 943-961

Moreno A, Valero-Garcés BL, Jiménez-Sánchez M, Domínguez-Cuesta MJ, Mata MP, Navas A, González-Sampériz P, Stoll H, Farias P, Morellón M, Corella JP and Rico M (2009) The last deglaciation in the Picos de Europa National Park (Cantabrian Mountains, northern Spain). Journal of Quaternary Science: doi: $10.1002 /$ jqs. 1265

Noren AJ, Bierman PR, Steig EJ, Lini A and Southon J (2002) Millennial-scale storminess variability in the northeast United States during the Holocene epoch. Nature 419: 821-824

O'Sullivan PE (1983) Annually-laminated lake sediments and the study of Quaternary environmental changes -- a review. Quaternary Science Reviews 1: 245-313

Paillard D, Labeyrie L and Yiou P (1996) Macintosh program performs time-series analysis. Eos Transactions 77: 379

Pérez-Obiol R and Julià R (1994) Climate change on the Iberian Peninsula recorded in a 30.000 yr pollen record from Lake Banyoles. Quaternary Research 41: 91-98

Pfister C, Luterbacher J, Schwarz-Zanetti G and Wegmann M (1998) Winter air temperature variations in western Europe during the Early and High Middle Ages (AD 750-1300). Holocene 8: 535-552

Pla S and Catalan J (2005) Chrysophyte cysts from lake sediments reveal the submillennial winter/spring climate variability in the northwestern Mediterranean region throughout the Holocene. Climate Dynamics 24: 263-278 
Pons A and Reille M (1988) The Holocene and upper Pleistocene pollen record from Padul (Granada, Spain): a new study. Palaeogeography, Palaeoclimatology, Palaeoecology 66: 243-263

Porter SC (1986) Pattern and forcing of Northern-Hemispere glacier variations during the last millennium Quaternary Research 26: 27-48

R Development Core Team (2008) R: A language and environment for statistical computing. R Foundation for Statistical Computing. Vienna, Austria

Reale O and Dirmeyer P (2000) Modeling the effects of vegetation on Mediterranean climate during the Roman Classical Period Part I: Climate history and model sensitivity. Global and Planetary Change 25: $163-184$

Reed JM, Stevenson AC and Juggins S (2001) A multi-proxy record of Holocene climatic change in southwestern Spain: the Laguna de Medina, Cadiz. Holocene 11: 707-719

Reimer PJ, Baillie MGL, Bard E, Bayliss A, Beck JW, Bertrand CJH, Blackwell PG, Buck CE, Burr GS, Cutler KB, Damon PE, Edwards RL, Fairbanks RG, Friedrich M, Guilderson TP, Hogg AG, Hughen KA, Kromer B, McCormac G, Manning S, Ramsey CB, Reimer RW, Remmele S, Southon JR, Stuiver M, Talamo S, Taylor FW, van der Plicht J and Weyhenmeyer CE (2004) IntCal04 Terrestrial Radiocarbon Age Calibration, 0 to 26 Cal Kyr BP. Radiocarbon 46: 1029-1058

Rico E, Chicote A, González ME and Montes C (1995) Batimetría y análisis morfométrico del lago de Arreo (N. España). Limnética 1 (11): 55-58

Roca JR and Julia R (1997) Late-glacial and Holocene lacustrine evolution based on ostracode assemblages in Southeastern Spain. Geobios 30: 823-830

Rodríguez-Pascua MA, Becker A, Calvo JP, Davenport. CA and Gómez-Gras D (2003) Sedimentart record of seismic events, with examples from recent and fossil lakes. In: B. Valero-Garcés (ed.), Limnogeology in Spain: a tribute to Kerry Kelts. Biblioteca de Ciencias. C.S.I.C., Madrid, pp. 253-281.

Romero-Viana L (2007) Paleolimnological study in two karstic lakes: climate signal in varved sediment and phototrophic organisms variability. Departament de Microbiología I Ecologia. Universitat de Valencia, Valencia, pp 180

Romero-Viana L, Julià R, Camacho A, Vicente E and Miracle M (2008) Climate signal in varve thickness: Lake La Cruz (Spain), a case study. Journal of Paleolimnology 40: 703-714

Rosell J (1994) Mapa Geológico de España y Memoria. Escala 1:50.000, Hoja de Tremp (252). Instituto Tecnológico Geominero de España (IGME), Madrid

Sadori L, Giraudi C, Petitti P and Ramrath A (2004) Human impact at Lago di Mezzano (central Italy) during the Bronze Age: a multidisciplinary approach. Quaternary International 113: 5-17 
Salrach JM (1995) La formación de la societat feudal. Ss. VI-XII. Història, Política, Societat i Cultura dels Països Catalans. Grup Enciclopèdia Catalana, Barcelona

Schnurrenberger DW, Russell JM and Kelts K (2003) Classification of lacustrine sediments based on sedimentary components. Journal of Paleolimnology 29: 141-154

Seager R, Graham N, Herweijer C, Gordon AL, Kushnir Y and Cook E (2007) Blueprints for Medieval hydroclimate. Quaternary Science Reviews 26: 2322-2336

Starkel LL (1991) The Vistula River Valley: a case study for central Europe. Temperate palaeohydrology pp 171-188

Strasser M, Stegmann S, Bussmann F, Anselmetti FS, Rick B and Kopf A (2007) Quantifying subaqueous slope stability during seismic shaking: Lake Lucerne as model for ocean margins. Marine Geology 240: 77-97

Thorndycraft VR and Benito G (2006) Late Holocene fluvial chronology of Spain: The role of climatic variability and human impact. Catena 66: 34-41

Valero-Garcés BL, González-Sampériz P, Delgado-Huertas A, Navas A, Machín J and Kelts K (2000a) Lateglacial and Late Holocene environmental and vegetational change in Salada Mediana, central Ebro basin, Spain. Quaternary International 73/74: 29-46

Valero-Garcés BL, Navas A, Machín J, Stevenson T and Davis B (2000b) Responses of a saline lake ecosystem in a semiaric region to irrigation and climate variability. Ambio 29: 344-350

Valero-Garcés BL, González-Sampériz P, Navas A, Machín J, Mata P, Delgado-Huertas A, Bao R, Moreno A, Carrión JS, Schwalb A and González-Barrios A (2006) Human impact since Medieval times and recent ecological restoration in a Mediterranean lake: the laguna Zoñar (Spain). Journal of Paleolimnology 35: 441-465

Valero-Garcés BL, Moreno A, Navas A, Machín J, Delgado-Huertas A, González-Sampériz P, Schwalb A, Morellón M and Edwards RL (2008) The Taravilla Lake and Tufa Deposits (Central Iberian Range, Spain) as paleohydrological and paleoclimatic indicators. Palaeogeography, Palaeoclimatology, Palaeoecology 259: 136-156

Wanner H, Beer J, Bütikofer J, Crowley TJ, Cubasch U, Flückiger J, Goosse H, Grosjean M, Joos F, Kaplan JO, Küttel M, Müller SA, Prentice IC, Solomina O, Stocker TF, Tarasov P, Wagner M and Widmann M (2008) Mid- to Late Holocene climate change: an overview. Quaternary Science Reviews 27: $1791-1828$ 
Weninger B and Jöris O (2004) Glacial Radiocarbon Calibration. The CalPal Program. In: C. B. R. a. C. O. T. Higham (ed.), Radiocarbon and Archaeology Fourth International Symposium, Oxford

Yll EI, Perez-Obiol R, Pantaleon-Cano J and Roure JM (1997) Palynological evidence for climatic change and human activity during the Holocene on Minorca (Balearic islands). Quaternary Research 48: 339-347

Zolitschka B (2007) Varved lake sediments. In: S. A. Elias (ed.), Encyclopedia of Quaternary Science. Elsevier, Amsterdam, pp 3105-3114 


\section{TABLES}

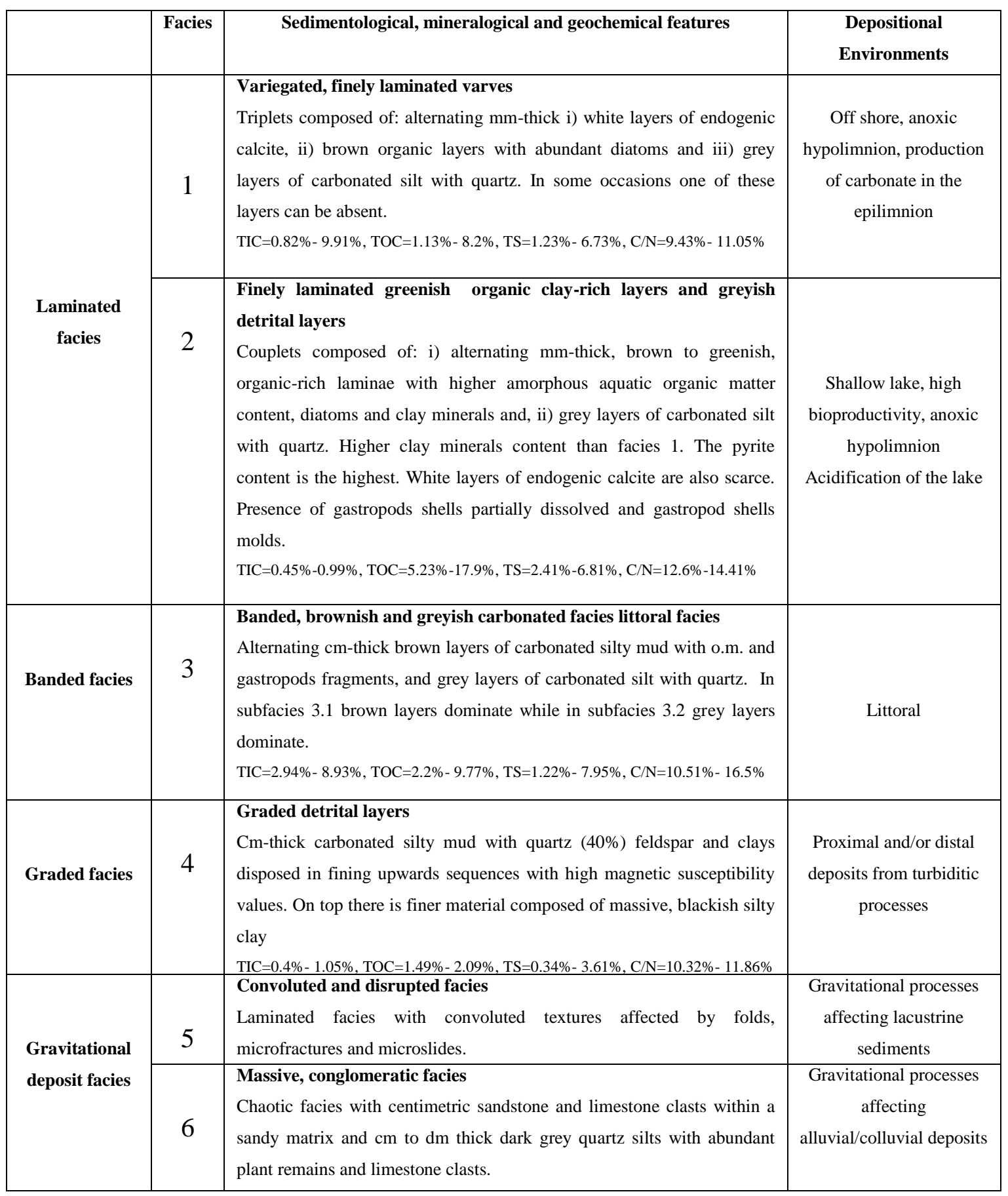

Table 1. Main sedimentological, mineralogical and geochemical (TIC, TOC, TS and C/N values) features and inferred depositional environments for the Montcortès Lake sedimentary facies. 


\begin{tabular}{lcc}
\hline & Comp.1 & Comp.2 \\
\hline Standard deviation & 24.809 & 19.578 \\
Proportion of Variance & 0.362 & 0.225 \\
Cumulative Proportion & 0.362 & 0.587 \\
\hline
\end{tabular}

Table 2. Principal Component Analysis (PCA) eigenvalues indicating the proportion and cumulative proportion of the variance explained by each eigenvector.

\begin{tabular}{|c|c|c|c|c|c|c|}
\hline Core Depth (m) & Lab code & Material & ${ }^{14} \mathrm{C}$ ages & Cal years BP ( $2 \sigma$ range) & Unit & Facies \\
\hline \multicolumn{7}{|l|}{ MON04-1A-1K } \\
\hline $0.29 \mathrm{~m}$ & Poz-23689 & Aquatic rest & $180 \pm 30$ & $170 \pm 110$ & II & 4 \\
\hline $2 \mathrm{~m}$ & Poz-23650 & Macrorest & $885 \pm 30$ & $830 \pm 60$ & IV & 4 \\
\hline $3.34 \mathrm{~m}$ & Poz-23651 & Macrorest & $1080 \pm 30$ & $1010 \pm 40$ & IV & 4 \\
\hline $6.69 \mathrm{~m}$ & Poz-9812 & Macrorest & $4030 \pm 35$ & $4500 \pm 50$ & VI & 2 \\
\hline \multicolumn{7}{|l|}{ MON04-2A-1K } \\
\hline $2.77 \mathrm{~m}$ & N-86494 & Charcoal+seeds & $1715 \pm 35$ & $1640 \pm 50$ & $\mathrm{C}$ & 3 \\
\hline $3.64 \mathrm{~m}$ & Poz-31027 & Macrorest & $2260 \pm 40$ & $1830 \pm 50$ & $\mathrm{C}$ & 3 \\
\hline $4.57 \mathrm{~m}$ & 144044 & Charcoal & $3950 \pm 30$ & $3890 \pm 60$ & $\mathrm{C}$ & 3 \\
\hline $5.44 \mathrm{~m}$ & $\mathrm{~N}-86495$ & Charcoal+seeds & $6580 \pm 35$ & $7490 \pm 40$ & $\mathrm{C}$ & 3 \\
\hline \multicolumn{7}{|l|}{ MON04-4A-1K } \\
\hline $0.72 \mathrm{~m}$ & Poz-13036 & Bulk sediment & $1290 \pm 35$ & $1240 \pm 40^{*}$ & IV & 4 \\
\hline $3.55 \mathrm{~m}$ & Poz-13035 & Bulk sediment & $1485 \pm 50$ & $1380 \pm 40$ & V & 1 \\
\hline $4.31 \mathrm{~m}$ & Poz-23652 & Macrorest & $3285 \pm 30$ & $3520 \pm 40$ & V & 1 \\
\hline 4.62 & Poz-23713 & Macrorest & $4090 \pm 40$ & $4650 \pm 120$ & VI & 2 \\
\hline $4.99 \mathrm{~m}$ & N-86496 & Charcoal & $2585 \pm 50$ & $2660 \pm 100 *$ & A & 7 \\
\hline $5 \mathrm{~m}$ & Poz-23690 & Macrorest & $6600 \pm 40$ & $7500 \pm 40^{*}$ & A & 7 \\
\hline $5.13 \mathrm{~m}$ & Poz-24949 & Macrorest & $8010 \pm 50$ & $8880 \pm 100^{*}$ & A & 7 \\
\hline $5.3 \mathrm{~m}$ & Poz-10328 & Macrorest & $6740 \pm 50$ & $7610 \pm 40^{*}$ & A & 7 \\
\hline $5.3 \mathrm{~m}$ & Poz-23771 & Bulk sediment & $10470 \pm 110$ & $12380 \pm 200^{*}$ & A & 7 \\
\hline
\end{tabular}

Table 3. Radiocarbon dates obtained in the Montcortès Lake MON04-1A-1K, MON04-2A-1K and MON04-4A-1K cores. The ages labelled with an asterisk have not been included in the age model. 


\section{FIGURE CAPTIONS}

Figure 1. Location of Montcortès Lake: (a) Geographical location within the Ebro River watershed. (b) Detailed geological map of the Montcortès Lake surrounding area. Lake catchment area is also indicated. (c) Bathymetrical map of Montcortès Lake and location of the four Kullenberg cores retrieved: $1 \mathrm{~A}$ (MON04-1A-1K), 2A (MON04-2A-1K), 3A (MON04-3A-1K) and 4A (MON04-4A-1K).

Figure 2. Lithostratigraphic correlation of the 4 cores retrieved in Montcortès Lake. Each core image is accompanied by its sedimentological description and magnetic susceptibility values. Dashed lines represent the correlation between the limits of the main sedimentary units. The position of the AMS ${ }^{14} \mathrm{C}$ dates in the cores is also indicated.

Figure 3. Sedimentological, compositional and mineralogical profile from the different litostratigraphic units and subunits defined from MON04-1 A-1K and MON04-4A-1K cores composition. AMS ${ }^{14} \mathrm{C}$ dates are indicated in the left side of the figure. (Qz: Quartz; Cc: Calcite; Clay minerals; Py: Pyrite; Gx: Gypsum).

Figure 4. Principal Component Analysis carried out with the geochemical (TIC, TOC, TS, TN and C/N), mineralogical and MS data from Montcortès Lake sequence. The arrows represent the analyzed variables and numbers indicate the position of every sample.

Figure 5. Chronological model of the sedimentary sequence based on the linear interpolation of 16 AMS ${ }^{14} \mathrm{C}$ dates. Estimated sedimentation rate for two different intervals are also indicated. Dashed line represents the age evolution of the littoral sedimentary deposition calculated trough the $4{ }^{14} \mathrm{C}$ dates obtained from 2A core. Dashed ovals surround AMS ${ }^{14} \mathrm{C}$ dates from 2A core.

Figure 6. Depositional evolution of Montcortès Lake during the last 6000 cal. yr BP based on selected proxies and comparison with other Iberian and Mediterranean paleorecords. From left to right: Sedimentary facies associations; PCA1: first main eigenvector; PCA 2: second main eigenvector; M.S.: Magnetic susceptibility; TOC: total organic carbon; TIC: total inorganic carbon; Estanya lake paleosalinity record (Morellón et al. 2008); Lake Redó altitude anomaly reconstruction (Pla and Catalan 2005); Mid-European lakes levels reconstruction (Magny 2006); $\delta^{18} \mathrm{O}$ per mil in Soreq Cave speleothem record (Israel) (Bar-Matthews et al. 2003), emplacement of the main human impact and land uses stages in the area and the paleolimnological and gravitational units. The main antrophic and land uses stages are: a) massive emigration from the Pyrenees; b) maximum in population due to industrialization; c) initiating with a depopulation due to black peast. Mostly agriculture and livestock diversification during this stage; d) increase in population, abundant fires and permanent land exploitation. 


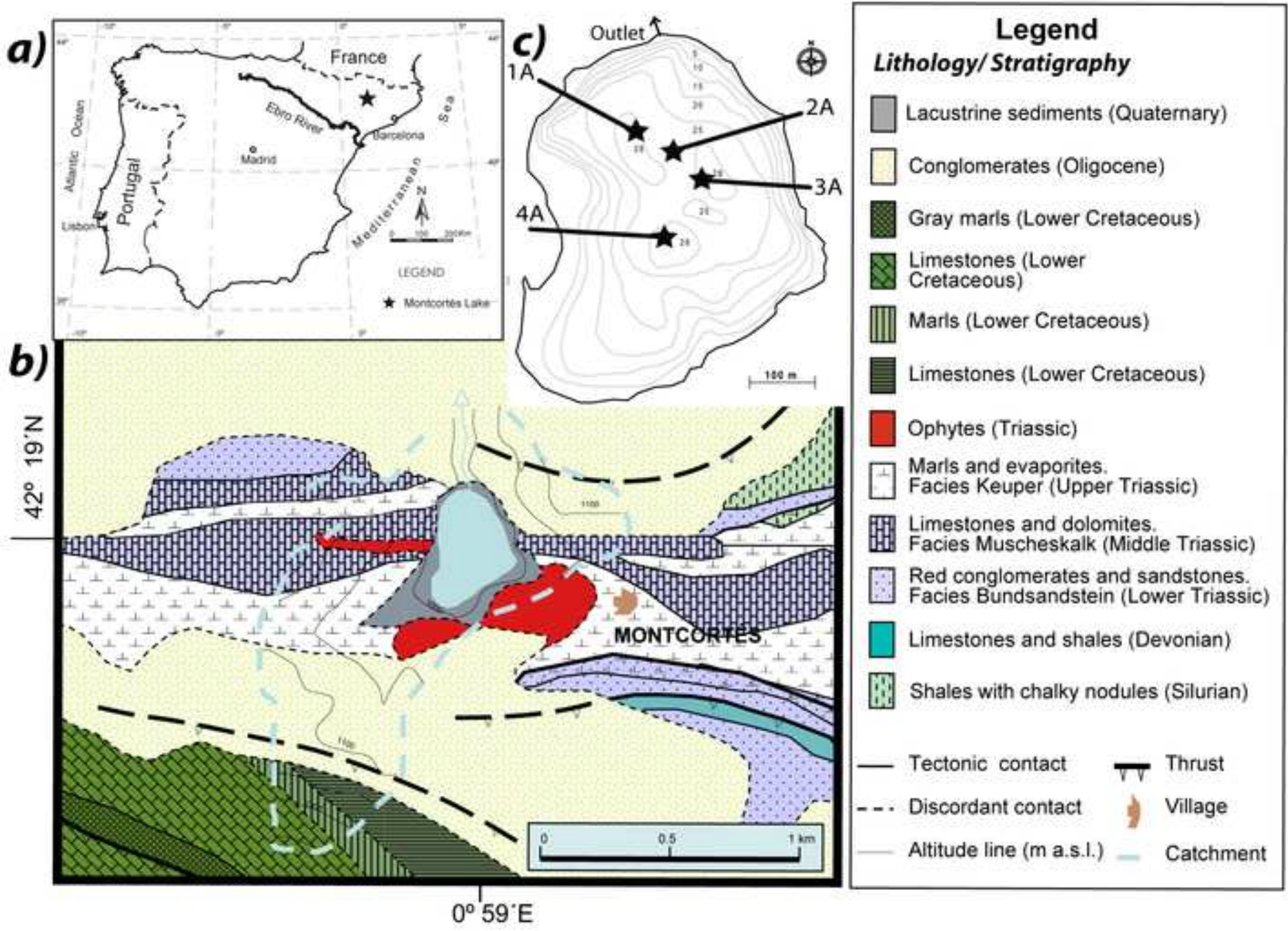


Click here to download high resolution image

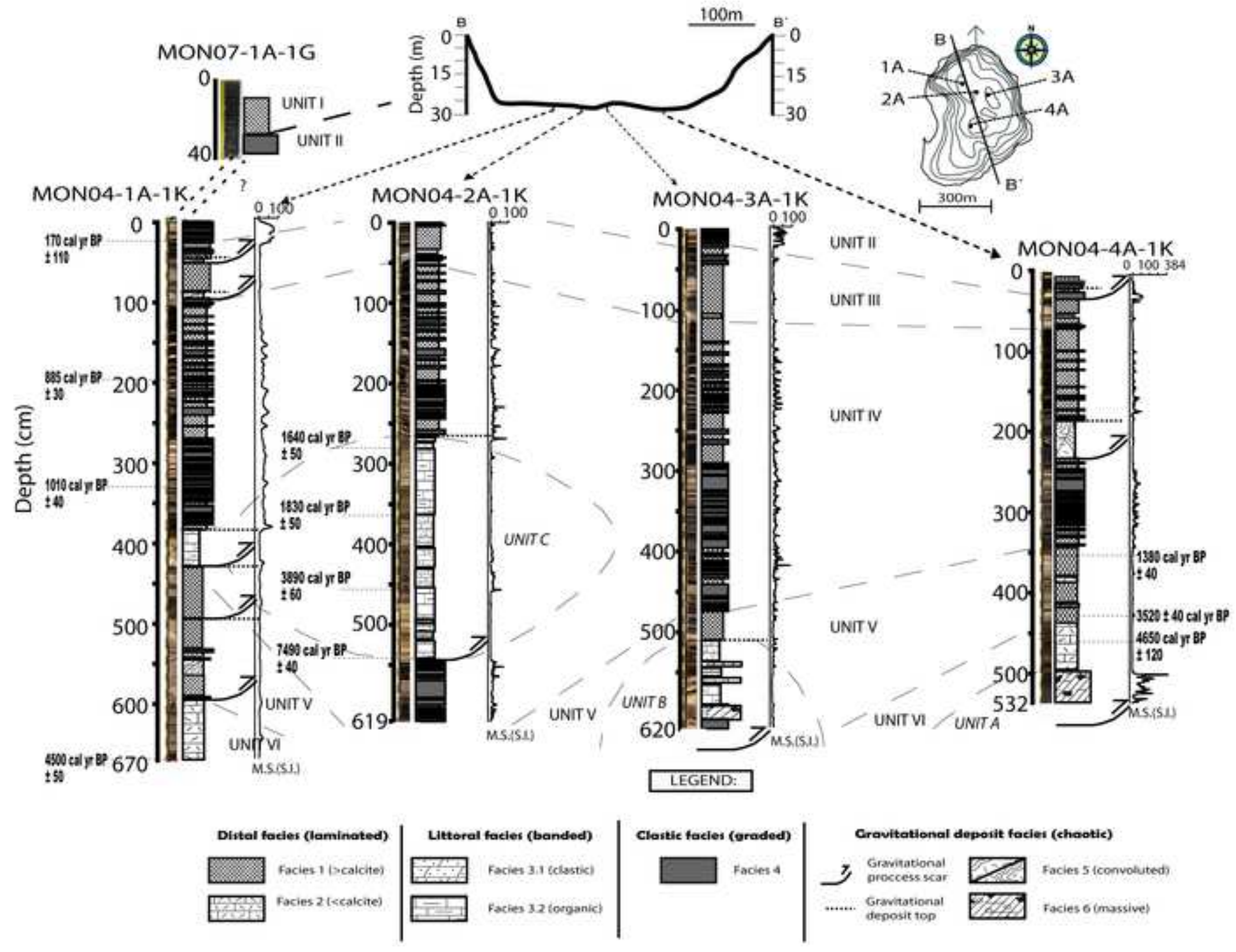




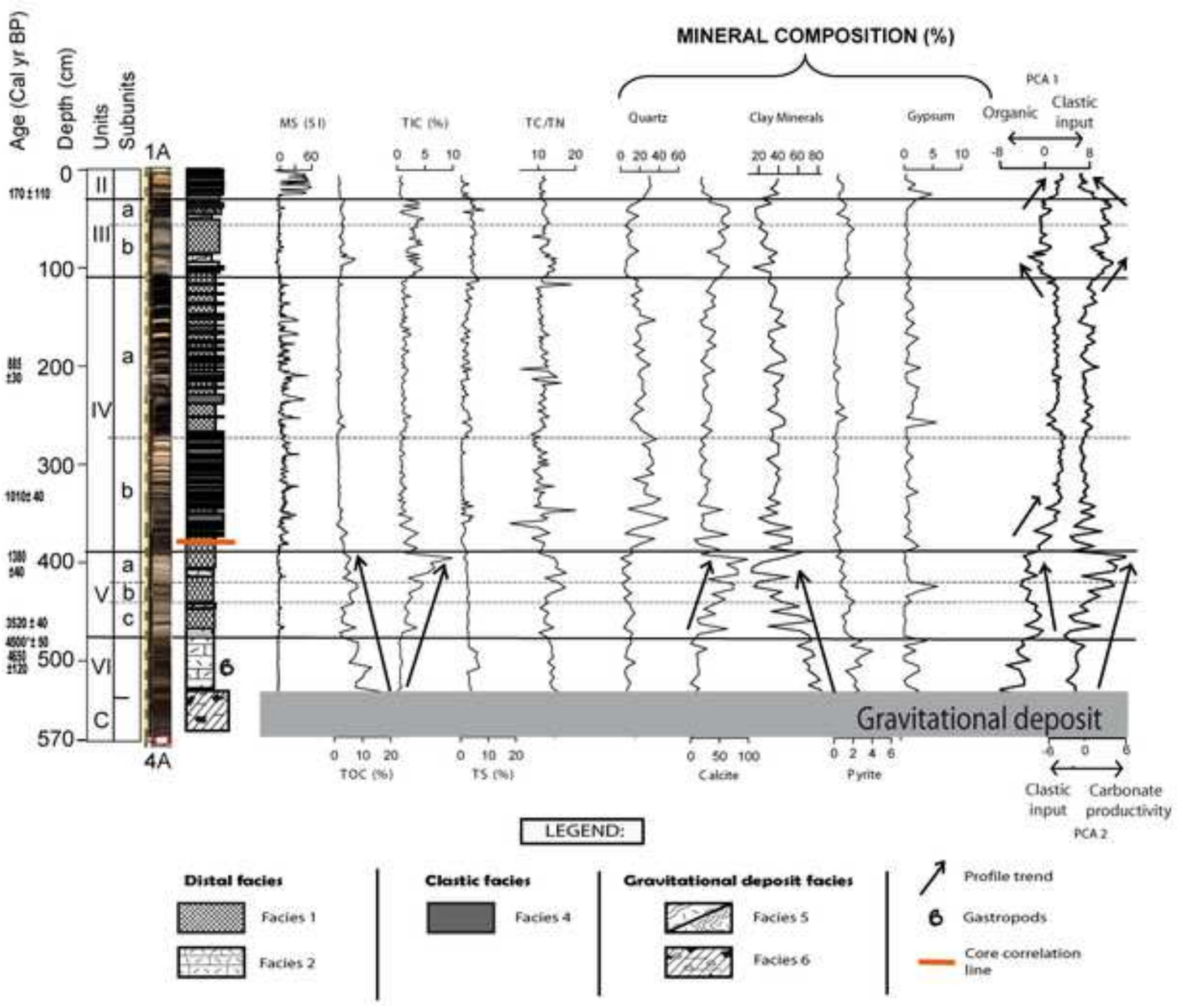




\section{gure 4}

Click here to download high resolution image

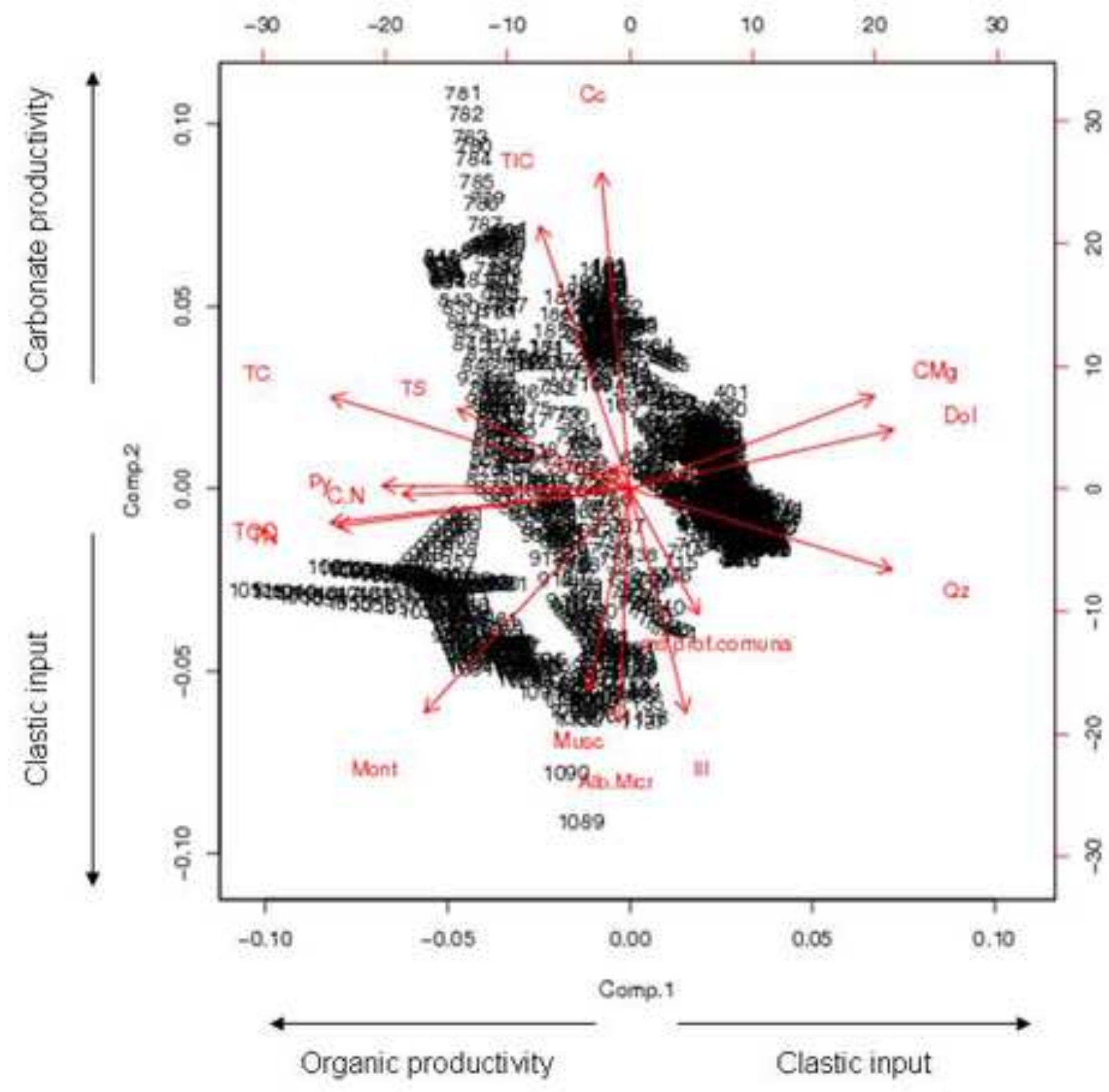




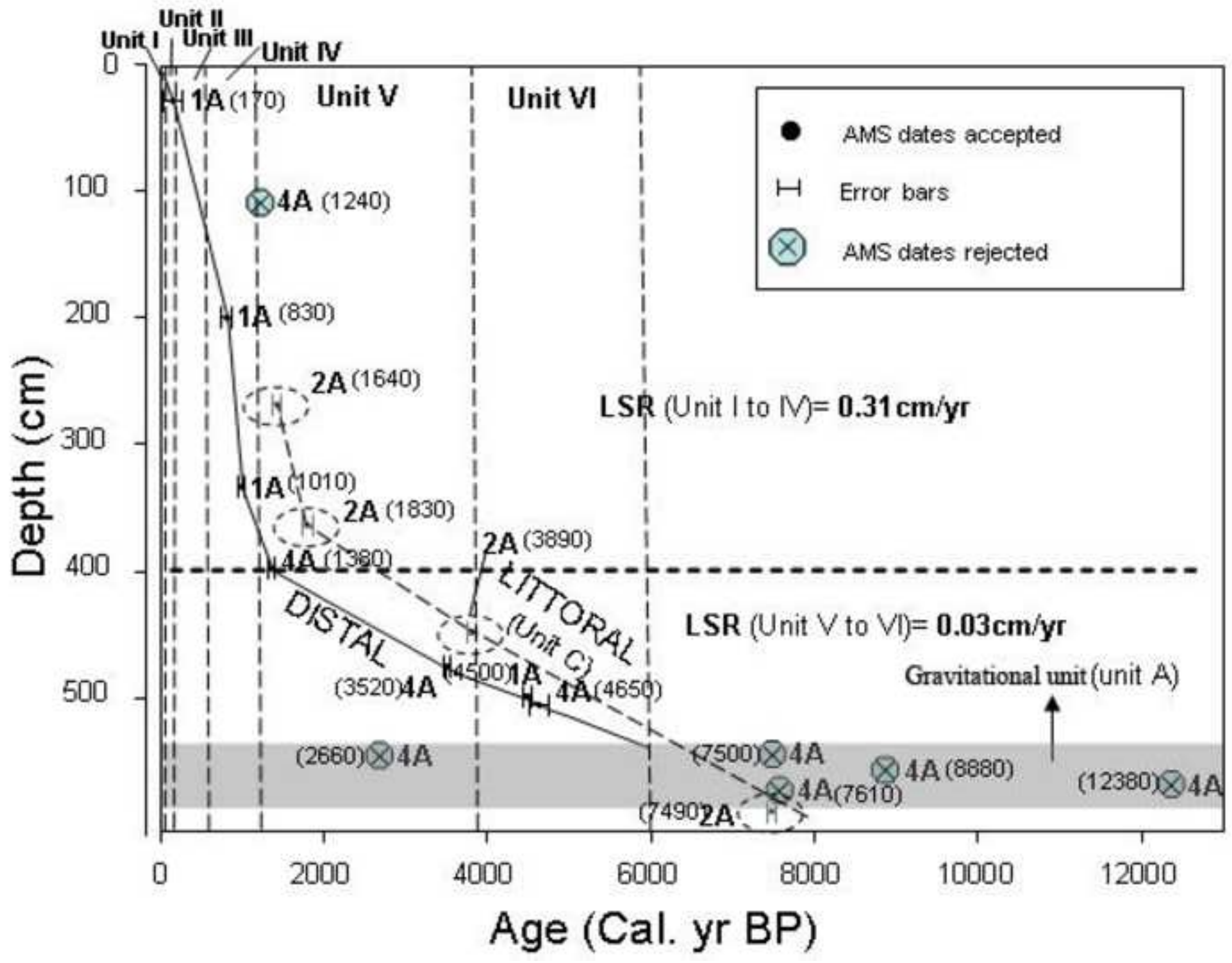




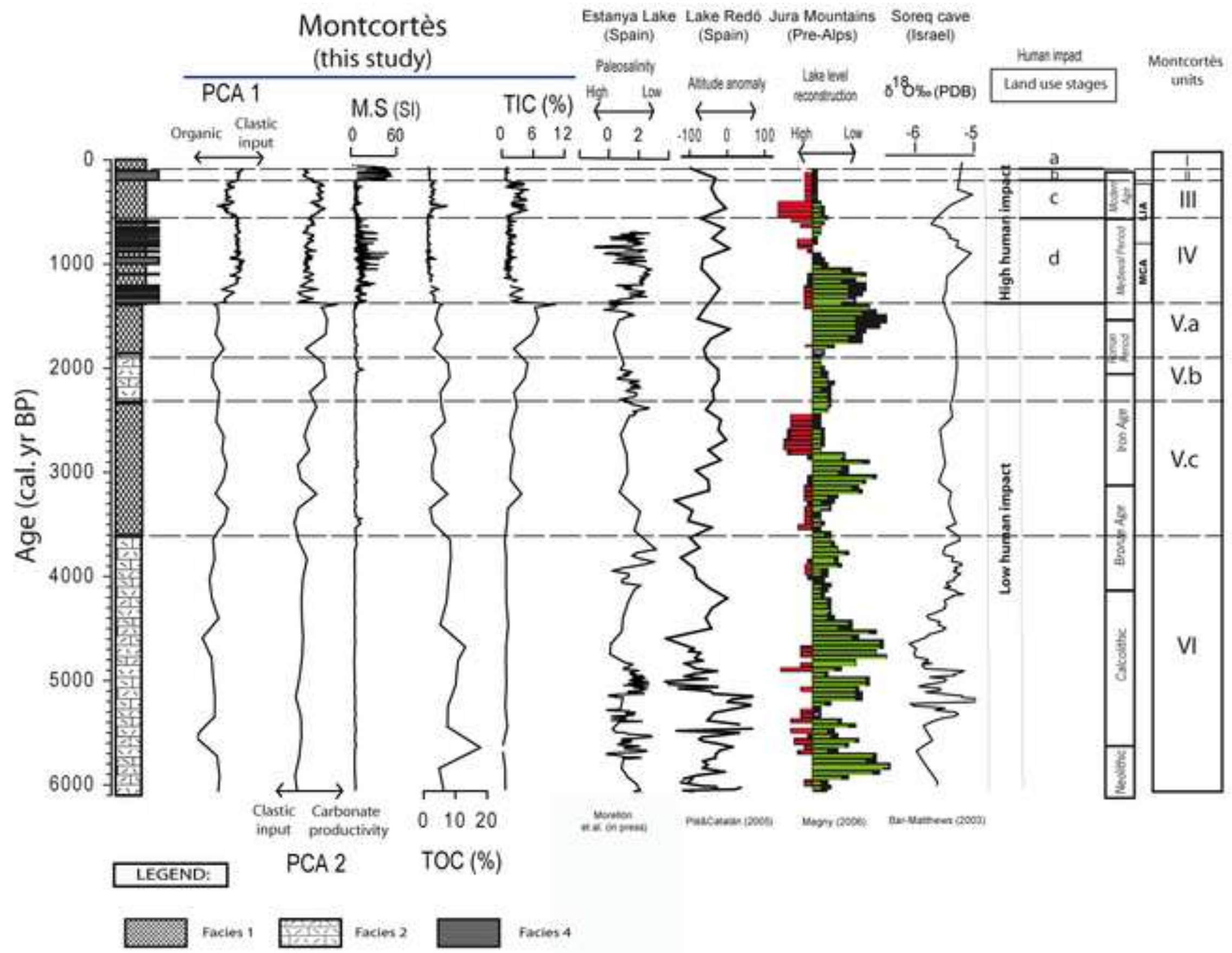

